\title{
Financial Flexibility and Investment Ability Across the Euro Area and the UK
}

DOI:

10.1111/eufm.12091

\section{Document Version}

Accepted author manuscript

Link to publication record in Manchester Research Explorer

\section{Citation for published version (APA):}

Ferrando, A., Marchica, M., \& Mura, R. (2017). Financial Flexibility and Investment Ability Across the Euro Area and the UK. European Financial Management, 23, 87-126. https://doi.org/10.1111/eufm.12091

\section{Published in:}

European Financial Management

\section{Citing this paper}

Please note that where the full-text provided on Manchester Research Explorer is the Author Accepted Manuscript or Proof version this may differ from the final Published version. If citing, it is advised that you check and use the publisher's definitive version.

\section{General rights}

Copyright and moral rights for the publications made accessible in the Research Explorer are retained by the authors and/or other copyright owners and it is a condition of accessing publications that users recognise and abide by the legal requirements associated with these rights.

\section{Takedown policy}

If you believe that this document breaches copyright please refer to the University of Manchester's Takedown Procedures [http://man.ac.uk/04Y6Bo] or contact uml.scholarlycommunications@manchester.ac.uk providing relevant details, so we can investigate your claim.

\section{OPEN ACCESS}




\title{
Financial Flexibility and Investment Ability across the Euro Area and the UK
}

\author{
Annalisa Ferrando \\ European Central Bank, DG-Economics \\ Kaiserstrasse 29 \\ D - 60311 Frankfurt am Main, Germany \\ annalisa.ferrando@ecb.int \\ phone: $+49(0) 69-13448729$ \\ Maria-Teresa Marchica* \\ Alliance Manchester Business School \\ University of Manchester \\ Crawford House, Booth Street East \\ Manchester, M13 9PL, United Kingdom \\ maria.marchica@manchester.ac.uk \\ phone: $+44(0) 161-2750121$
}

\section{Roberto Mura}
Alliance Manchester Business School
University of Manchester
Crawford House, Booth Street East
Manchester, M13 9PL, United Kingdom
roberto.mura@manchester.ac.uk
phone: $+44(0) 161-2750120$

\footnotetext{
We thank John Doukas (the Editor), two anonymous referees, Nataliya Zaiats, Philipp Hartmann, and seminar participants at the European Commission workshop 2015, European Central Bank (ECB), at the Eastern Finance Association 2013 conference, European Economic Association 2013, World Finance \& Banking Symposium 2013, and at the International Finance \& Banking Association 2013 conference. This research was conducted while Marchica and Mura were visiting the ECB, whose hospitality and support are gratefully acknowledged. The views expressed in this paper reflect only those of the authors and should not be attributed to the ECB.

* Corresponding author
} 


\title{
Financial Flexibility and Investment Ability across the Euro Area and the UK
}

\begin{abstract}
We use a very large sample of European private and public firms to show that financial flexibility attained through a conservative leverage policy is more important for private, small-medium-sized, and young firms and for firms in countries with less access to credit and weaker investor protection. Further, using the 2007 financial crisis as a natural experiment, we show that a higher degree of financial flexibility allows firms to reduce the negative impact of liquidity shocks on investment. Our findings support the hypothesis that financial flexibility improves companies' ability to undertake future investment, despite market frictions hampering possible growth opportunities.
\end{abstract}

Keywords: low leverage, financial flexibility, investment, cross-country analysis JEL Classification: G31, G32, D92 


\section{Introduction}

Under perfect capital markets, firms may always invest at their optimum level and costlessly adjust their financial structures to any unexpected change in liquidity and growth opportunities. However, when capital markets are imperfect and the cost of external financing increases, financial flexibility becomes increasingly important. Generally speaking, financial flexibility relates to the ability of companies to undertake investment in the future, when asymmetric information and contracting problems might otherwise force them to forego profitable growth opportunities. Firms may pursue financial flexibility in several ways: by shaping their capital structure, cash management or payout policies, and by creating "an intertemporal dependence" between financial and investment decisions (Almeida et al., 2011; Denis, 2011).

Our paper focuses specifically on financial flexibility attained through a conservative leverage policy. Survey evidence suggests that financial flexibility is a primary driver of chief financial officers' leverage choices (Graham and Harvey, 2001; Bancel and Mittoo, 2004; Brounen et al., 2006). Companies may follow a conservative leverage policy to maintain "substantial reserves of untapped borrowing power" (Modigliani and Miller, 1963, p. 442), which allows them to access the capital markets in the event of positive shocks to their investment opportunity set. The value of being financially flexible is thus directly related to the ability of companies to undertake new investment projects: the more the investment undertaken by financially flexible (FF) firms, the higher the value of financial flexibility for those firms. Indeed, several empirical studies provide evidence that supports this statement: the sensitivity of investment to a firm's financial flexibility status is significantly higher for firms that attained their flexibility through either conservative leverage (Marchica and Mura, 2010; and de Jong et al., 2012) or a zero-leverage policy (Bessler et al., 2013).

The present paper takes the additional step of analyzing how the value of financial flexibility varies depending on the degree of financing frictions companies face. In their 
theoretical model, Gamba and Triantis (2008) predict that "firms with high level of financial flexibility should be valued at a premium." Consequently, for firms with lower cost of external financing, this premium should be smaller. Therefore, we reason that, in the presence of market friction, firms that anticipate valuable future investment opportunities may follow a policy of financial flexibility to preserve their ability to pursue these future growth options. Once they acquire FF status, these firms should be able not only to invest more than non-flexible ones (Not FF), they should also be able to invest more the stronger the degree of financing constraints. In other words, the value of financial flexibility should be positive and it should be greater for those FF firms expecting to face more financing constraints. A further implication is therefore that, in the presence of exogenous shocks to liquidity in the market, FF firms should better be able to cope with a rationed capital supply and to avoid financial distress.

To test our hypotheses, we use the entire universe of Bureau van Dijk's Amadeus, which encompasses a very large sample of 289,839 European companies with at least 4 years of observations in the 18-year interval 1993-2010. Thanks to reporting requirements and practices across most European countries, this database gives us the opportunity to be the first to investigate the value of financial flexibility across a very heterogeneous sample of both publicly traded and privately held firms that vary substantially in size, age, and quality of institutional setting. This sample, from eight euro-area countries and the UK, represents a very large proportion of the aggregate economic activity of Western Europe. ${ }^{1}$

We first identify FF firms by focusing on low-leverage firms. We estimate a leverage equation from which we calculate the predicted level of debt. Since the demand for financial flexibility is indirectly captured by the negative deviations from estimated target leverage (LL), we classify a firm as FF if it shows an LL policy for a minimum number of consecutive years.

\footnotetext{
${ }^{1}$ For instance, based on National Accounts of each Western European country, we calculate that, at the end of 2010 , the total non-government gross fixed capital formation of all countries in our sample was almost $84 \%$ of the equivalent aggregate in Western Europe. Figures for the proportion of overall GDP (83.2\%) and total employment $(86.2 \%)$ are similar.
} 
We find that $31 \%$ of firms in our sample show a conservative leverage policy for at least three consecutive years (FF3). Second, we test whether this degree of financial flexibility has any impact on investment ability. In the presence of market frictions, firms that anticipate valuable growth options in the future may respond by pursuing an LL policy for a number of years. In this way, FF firms may have enough spare borrowing power to be able to raise external funds, and to invest more in the years following the conservative financial policy. To test this hypothesis, we use a modified version of the q-model of investment augmented by an FF dummy and its interaction term with cash flow. The FF dummy is expected to have a positive and significant impact on capital expenditure. In addition, to the extent that FF firms can, after a period of low leverage, more easily raise external funds to finance their projects, their investment ability should be less dependent on internal funds. As a consequence, we would expect a lower sensitivity of investment to cash flow. The results over the entire sample do indeed show a large impact from FF status on firm investment ability. Our tests reveal that the average company that maintains an LL policy for three years can increase its capital expenditure by $22.6 \%$. These results are robust to the method we follow to classify FF firms, to alternative definitions of leverage and growth opportunities, and to alternative interpretations, such as credit rationing and agency issues.

Once we show that the value of financial flexibility relates to the ability of firms to invest (i.e., positive investment sensitivity to FF status), we test the hypothesis that financial flexibility is more valuable for those companies that face higher external financing costs. To this end, we classify different subsamples of firms based on their expected financing friction. For each subsample, we run our baseline model and compare the overall impact of FF status on firm investment. We show that: 1) privately held companies (after maintaining an LL policy for at least three years) increase their capital expenditures almost four times more than publicly traded firms $(22.6 \%$ versus $6.9 \%)$; 2) small companies are able to increase their capital 
expenditures by $16.1 \%$, while large companies can increase their investment by $15.6 \%$; 3) young FF companies increase their capital expenditures by $25.7 \%$, while mature FF firms increase them by $9 \%$.

We further our investigation by exploiting the heterogeneity of the quality of institutional settings in our sample. Lower legal protection increases firms' expected asymmetric information and contracting problems, which, in turn, negatively affects corporate financial and investment decisions (e.g., La Porta et al., 1997; Love, 2003; Mclean et al., 2012; Mortal and Reisel, 2013). We expect financial flexibility to be more valuable for firms in countries with lower legal protection. Indeed, our results show that in countries with limited credit accessibility, FF companies are able to increase their investment by almost $22.7 \%$, while in countries with better access, FF firms increase their investment by only $7.9 \%$. We find the same remarkable difference $(22.4 \%$ vs. $9.4 \%)$ when we consider the level of investor protection.

Finally, we investigate whether FF status allows companies to reduce the negative impact of liquidity shocks. The 2007 financial crisis offers a natural experiment to test this hypothesis. We argue that spare borrowing capacity should allow FF firms to invest relatively more than others during a period of crisis. We observe that during the 2007 financial crisis, all firms invest, on average, less than in the preceding four years. More importantly, FF firms seem to be able to divest significantly less than others: during the financial crisis, the reduction in their capital expenditure is $6.8 \%$, while for the Not FF firms it is $14.4 \%$ (13.8\% for a subsample of matched Not FF firms). We also show that the preferred financing method for FF firms is leverage, which increases by $8.4 \%$. This supports the hypothesis that after a period of spare debt capacity, FF firms are able to invest more by raising more debt. Finally, FF companies also seem to be less exposed to market imperfections even during the severe conditions of the recent crisis, as suggested by their lower sensitivity of investment to cash flow. 
Our study complements a growing literature on financial flexibility, in a number of ways. Gamba and Triantis (2008) theoretically discuss the role of financial flexibility on firm value. Marchica and Mura (2010) provide empirical evidence on how financial flexibility achieved by a leverage-conservative policy affects investment ability and long run performance of UK publicly traded companies. Similar findings on publicly traded US firms are reported by De Jong et al. (2012), who also show that firms that borrow less in unconstrained periods are more likely to issue debt during financial crises. Bessler et al. (2013) find, in a cross-country sample of public companies, that firms pursuing a zero-leverage policy for a short period are able to invest more in the future than others. Denis and McKeon (2012) identify long-term investment as the primary purpose of large debt increases for US-quoted firms, while Kahl et al. (2015) point out that commercial paper provides financial flexibility to firms with uncertain prospects and funding needs. A number of studies highlight the role of cash management only in preserving firms' financial flexibility (Ang and Smedema, 2011; and Brown and Petersen, 2011), while others show how a combination of different policies helps firms to increase their investment, possibly leading to less severe effects from the recent financial crisis (e.g., Bancel and Mittoo, 2011; Arslan-Ayaydin et al., 2014; Rapp et al., 2014).

To the best of our knowledge, we are the first to empirically analyze the role played by financial flexibility for a very large sample of both public and private European companies. Our paper provides new evidence on how the value of financial flexibility changes across firms that face different degrees of financial constraints. In addition, we generate direct evidence that companies that achieved FF status through a conservative leverage policy are able to invest more than those that did not, even in the presence of an exogenous liquidity shock as severe as the most recent financial crisis.

Further, our results on privately held companies contribute to a recent line of studies that examine the differences between public and private firms' financial policies (Brav, 2009; 
Saunders and Steffen, 2011; Schoubben and Van Hulle, 2011; and Asker et al., 2014;) and investment choices (Sheen, 2011; Gilje and Taillard, 2013; Mortal and Reisel, 2013; Asker et al., 2014; and Lyandres et al., 2015). Our paper adds new results to this growing literature. By analyzing the relation between financial and investment strategies, we show that privately held firms are likely to invest more after a period of conservative leverage policy.

Further, our findings relate to the literature on investor protection and investment decisions (e.g., La Porta et al., 1997; Mortal and Reisel, 2013) by showing that the quality of institutional settings matters for FF firms. Firms in countries with poorer legal protections and less developed capital markets are more likely to benefit from pursuing financial flexibility through a conservative leverage strategy.

Finally, this paper holds important policy implications. In 2015, the European Commission launched a plan to mobilize capital in Europe (the Capital Markets Union), to channel it to all companies, including small-medium firms (SMEs), and infrastructure projects that seek to expand and create jobs. ${ }^{2}$ The plan recognizes the central role played by SMEs in the EU economy. The 20 million European SMEs play an important role in the EUeconomy, as they provide $67 \%$ of private sector jobs and contribute more than $58 \%$ of the total valueadded created by businesses in Europe. ${ }^{3}$ Therefore, the SME sector is indeed the true backbone of the European economy. Our evidence sheds light on (one of) the mechanisms through which SMEs tackle potential financial frictions that may otherwise hamper their development and growth. Their greater dependence on bank lending makes SMEs more vulnerable when bank lending tightens, as happened in the financial crisis.

The remainder of this paper proceeds as follows. In Section 2, we describe the data and present the measure of financial flexibility. Sections 3 and 4 set forth the empirical results and all robustness tests, respectively. Finally, Section 5 describes our conclusions.

\footnotetext{
${ }^{2}$ http://ec.europa.eu/finance/consultations/2015/capital-markets-union/docs/green-paper_en.pdf.

${ }^{3}$ http://ec.europa.eu/growth/smes/business-friendly-environment/performance-review/files/supportingdocuments/2014/annual-report-smes-2014_en.pdf
} 


\section{Sample and financial flexibility measure}

\subsection{Data collection and sample}

We use the entire universe of Amadeus for accounting data (both balance sheets and income statements). Amadeus, a product of Bureau van Dijk, is a comprehensive, pan-European database containing accounting information for both publicly traded and privately held companies. Bureau van Dijk collects accounting information directly from a variety of sources, such as official registers, regulatory bodies, annual reports, private correspondence, company websites and news reports, and indirectly from Bureau van Dijk-associated information providers. It further harmonizes the financial accounts to allow accurate cross-country comparisons. Typically, one annual release of Amadeus covers at most the preceding 10 accounting years of each firm. Further, Amadeus removes a firm after at least five years of no reporting data. To eliminate this potential survivorship bias, we compile our database by collecting accounting information from each annual release retrospectively so that we can have the complete history of data for all firms across the entire sample period, similar to previous studies using this database (e.g., Kalemli-Ozcan et al., 2015).

The original data set contains end-of-year accounting information for the period 19902010. We drop the first two years because of poor coverage, and we lose another year of observations to compute some of our variables, such as sales growth. We eliminate observations when there are inputting mistakes (e.g., negative total assets). We winsorize all variables at the top and bottom $1 \%$ of their distribution within each country. After performing our data filtering, the unbalanced panel comprises 685,693 firms and 5,522,225 firm-year observations over the 1993-2010 period, across 8 euro area countries (Belgium, Finland, France, Germany, Italy, Netherlands, Portugal, and Spain), and the UK. 
We use this sample to estimate the predicted leverage for each firm each year. We then require firms to have at least four consecutive years of observations, so as to have enough information to build our proxies of FF status (FF dummies). (Please see Section 2.2 below for more details.) The final sample we use in the investment analysis comprises $1,598,899$ firmyear observations, from 289,839 unique firms. ${ }^{4}$

\subsection{Identification of LL and FF firms}

Recent survey studies of capital structure choices provide strong evidence that the single most important determinant of leverage decisions by firms is the desire to maintain financial flexibility (e.g., Graham and Harvey, 2001; Bancel and Mittoo, 2004; Brounen et al., 2006). In their theoretical model, DeAngelo and DeAngelo (2007) state that financial flexibility "is the critical missing link for an empirically viable theory." However, since there is no well-defined measure of flexibility in the literature, this is an unobservable factor that depends largely on managers' assessment of future growth options. Consequently, this factor will end up in the residual of the leverage model, where it will generate systematic deviations between observed and estimated leverage. The deviations from predicted target leverage are thus used to capture indirectly the effect of financial flexibility.

For each country we estimate a dynamic partial adjustment leverage model using the Generalized Method of Moments (GMM) technique and calculate the fitted values of leverage

\footnotetext{
${ }^{4}$ Detailed comparative descriptive statistics show that the sample we use for the investment analysis is highly comparable to the sample we use for the leverage models. There appears to be no distortion or bias introduced by the filtering necessary to obtain the final sample for the investment analysis.
} 
following Faulkender et al. (2012). We report definitions of all variables in Appendix A. Results of the leverage regressions are reported in Appendix B. ${ }^{5}$

We then compare the fitted values with the actual values, and we define as LL those firms that exhibit a negative deviation between actual and predicted leverage. As discussed above, we expect the systematic component of these deviations to be due to the unobserved effect of financial flexibility in the leverage model. To ensure that we are indeed observing a policy, not just a transitory shock to the capital structure of the firm, we classify a firm as FF if: 1) the deviation is larger than $5 \%$; and 2) the firm is in a low-leverage state for a minimum number of consecutive periods. Further, we separate FF companies from those that show an actual level of leverage always below the predicted level. This is because it does not seem that these firms, unlike FF firms, are following a conservative leverage policy to boost their future investment ability.

In the baseline specification, the FF dummy takes the value of 1 when we observe at least three consecutive periods in which the firm is classified as LL (FF3). There is no theoretical rationale for choosing a specific time length. Therefore, to assess whether the results are sensitive to the choice of time horizon, we use alternative proxies, defined over a period of three to five years of leverage conservatism.

\subsection{Value of financial flexibility}

To measure the value of financial flexibility, we start from the conjecture that, in the presence of market frictions, firms that anticipate valuable growth options in the future may respond by pursuing an LL policy for a number of years. As noted in Myers (1984), reserves of borrowing

\footnotetext{
${ }^{5}$ We estimate the leverage model for each country to better clean the residuals from any unobservable country characteristics that might influence each control variable included in the model. Results from the pooled sample are virtually identical to those reported in the paper.
} 
power enable FF firms to raise external funds and to invest more in the years following the conservative financial policy. We use a modified q-model of investment, in which capital expenditure is regressed on Sales Growth and Cash Flow at the beginning-of-year in line with the large literature on investment (e.g., Fazzari et al., 1988; Cleary, 1999; Alti, 2003; Brown and Petersen, 2009). We augment the model with the FF status dummy, and an interaction term between this dummy and cash flow to test whether FF firms do have enhanced investment ability and a lower sensitivity of investment to cash flow. The value of financial flexibility is therefore captured by the sensitivity of investments to FF status. It is important to note that LL and FF status are observed before the investment is undertaken. This (partly) controls for a potential simultaneity between leverage and investment decisions. We estimate the following investment model over the entire sample:

$$
\begin{aligned}
& \frac{\Delta \text { Gross PPE }_{i, t}}{K_{i, t-1}}=\gamma_{1} \frac{\Delta \text { Gross PPE }_{i, t-1}}{K_{i, t-1}}+\gamma_{2} \frac{\text { Cash Flow }_{i, t-1}}{K_{i, t-1}}+\gamma_{3} \text { Sales Growt }_{i, t}+\gamma_{4} F F_{i, t} \\
& +\gamma_{5} F F_{i, t} \times \frac{\text { Cash Flow }_{i, t-1}}{K_{i, t-1}}+\eta_{i}+\eta_{t}+v_{i, t}
\end{aligned}
$$

where $\frac{\Delta \operatorname{Gross} P P E_{i, t}}{K_{i, t-1}}$ represents the capital expenditure of firm $i$ at time $t$ relative to the beginningof-year capital stock $\left(K_{i, t-1}\right)$. Capital expenditure is computed as the annual change in (net) total fixed assets plus depreciation. Capital stock is constructed using the perpetual inventory method (please see Appendix A for more details). $\frac{\text { Cash Flow }_{i, t-1}}{K_{i, t-1}}$ is the ratio of operating profits before tax, interest, and preferred dividends, plus depreciation of fixed assets to capital stock at the beginning-of-year; Sales Growth is a proxy for growth opportunities and is equal to annual growth rate of sales. We also include firm fixed effects $\left(\eta_{i}\right)$ and time-specific effect $\left(\eta_{t}\right)$ to capture any macroeconomic shock over our sample period. $v_{i t}$ is the disturbance term, assumed to be serially uncorrelated, with mean zero. We use the GMM technique in a dynamic framework, similar to Bond et al. (2003), to control for both endogeneity and omitted variable bias due to unobservable firm characteristics. In each regression, we use all suitable lags of 
independent variables as instruments. We expect the FF dummy to have a positive and significant impact on the capital expenditure of firms and the interaction term to be negative. In fact, given their spare debt capacity, FF companies should be able to raise external funds to finance their projects, thus leaving them less dependent on internal resources.

\section{Empirical results}

\subsection{Univariate analysis}

Table 1 reports the coverage of our initial sample. One third of the total sample is made up of Spanish firms, which together with French and Italian firms, represent $85 \%$ of the entire sample. We acknowledge that subsamples of German and Dutch companies, in particular, may be underrepresented in the Amadeus sample. One advantage of Amadeus is the high incidence of privately held firms, which represent $99.7 \%$ of our sample.

[INSERT TABLE 1 HERE]

Firm size varies substantially across countries. The mean overall value of total assets per firm in our sample is $€ 13.313$ million, with the lowest mean value for Spanish firms (€5.064 million) and the highest for German firms (€316.10 million). Nonetheless, the percentage of SMEs is very high: over $90 \%$ in France, Italy, Spain, Finland and Portugal, around $80 \%$ in the UK and Belgium, but less than $60 \%$ in Germany and less than $50 \%$ in Netherlands. This is in line with figures provided by the European Commission on SMEs' impact on the EU labor market in 2008, which shows that most European businesses are, in fact, SMEs. In general, there is also large heterogeneity across countries in terms of age (this seems similar to the Vismara et al., 2012 evidence for a sample of European IPO firms). The mean (median) age of firms in our sample is 16 (13) years, with Dutch firms having a mean age of 34 years and Spanish firms 12 years. 
Table 2 reports brief descriptive statistics of all accounting variables we use in the investment model for the whole sample. Figures on capital expenditure and cash flow $\left(\frac{\Delta{\text { Gross } P P E_{i, t}}_{K_{i, t}}}{\text { and }} \frac{\text { Cash Flow }_{i, t-1}}{K_{i, t-1}}\right)$ for the whole sample are in line with Becker and Sivadasan (2010).

\section{[INSERT TABLE 2 HERE]}

Table 3 reports statistics on the percentage of firms identified as financially flexible at least once over the entire sample period. Across the whole sample, $31.2 \%$ of firms (mostly privately held companies) follow a conservative leverage policy for at least three years. We then define subsamples of firms according to size and age. Small, medium, and large firms are identified on the basis of the tertile distribution of the natural logarithm of total assets in each country each year. Young (mature) firms are those in the bottom (top) tertile of the age distribution in each country each year. Age is defined as the number of years from the year of incorporation. The average age of young firms is less than 5 years; while the average age of mature firms is about 17 . Almost $15 \%$ of firms are classified as small and financially flexible, while more than $20 \%$ are young and financially flexible. Further, most FF firms are in countries with limited access to credit, poorer investor protection, and less developed financial markets.

\section{[INSERT TABLE 3 HERE]}

\subsection{Investment baseline results}

Table 4 shows the results of the investment model. FF dummies here are defined on the basis of LL spanning between three and five years. The relation between capital expenditure and Sales Growth is positive and significant, consistent with the prediction that growth opportunities play a relevant role in investment decisions. The coefficient on Cash Flow is always positive and significant, suggesting that the presence of capital market imperfections may result in firms relying, at least partially, on internal funds for investment.

[INSERT TABLE 4 HERE] 
Most importantly, FF dummies are positive and statistically significant across all specifications, suggesting that companies that undergo a period of conservative leverage tend to invest more. Further, we find that investment sensitivity to cash flow is always negative and statistically significant. This result indicates that FF companies are less exposed to capital market imperfections, and their ability to invest is thus at a minimum and no more jeopardized by asymmetric and agency cost problems than for other firms. The impact of the FF status dummy is also economically sizeable. For instance, after at least three years of conservative leverage policy (FF3), a company with average cash flow (approximately 0.595) is able to increase its average investment by about $22.6 \% .^{6}$

\subsection{Robustness tests}

To verify the robustness and interpretation of our results above, we deploy several tests.

\subsubsection{Alternative definitions}

Financial flexibility status. First, we use a more stringent criterion to define FF status. The first three columns of Table 5 report results where we require the deviation of actual leverage from the target to be greater than $10 \%$. In this case, it is more valuable for firms to be financially flexible, as the impact on investment is, on average, almost three additional percentage points higher than the main findings. For instance, after at least three years of conservative leverage policy (FF3-10\%), a company with average cash flow (approximately 0.595 ) is able to increase its average investment by $25.4 \%$.

\footnotetext{
${ }^{6}$ The economic impact for column (1) in Table 4, for instance, is computed as: $0.139 \times 1-0.072 \times 0.595=0.096$. We then compare this with the average level of capital expenditure (0.426) and obtain an economic impact of $22.6 \%$. For robustness purposes, we also estimate the investment model as in Table 4 for each country. Unreported results show that the FF dummy is positive and statistically significant across all countries, and its interaction with cash flow is always negative and statistically significant.
} 
Second, we define a company as financially flexible if it maintains a zero-leverage policy for a minimum of three consecutive years. Results when we use this definition are reported in column (4) of Table 5, and they are similar to the baseline results; these firms significantly increase their capital expenditure after a period of "extremely conservative" leverage policy. This complements the Bessler et al. (2013) evidence and builds on previous studies that show that public, dividend-paying companies raise debt neither to mitigate investment distortions in the UK (Dang, 2013) nor to accommodate managers' personal preferences in the US (Strebulaev and Yang, 2013).

Firms always with below-predicted leverage. In our baseline settings, we separate the FF companies from those that show an actual level of leverage always below the predicted level. We conjecture that our FF firms choose to adopt a conservative policy for a period of time to preserve their ability to pursue bigger and better growth options in the future. Therefore, in our baseline tests, these "always flexible" firms are classified as Not FF. However, it could be argued that these "always flexible" firms are those that value their financial flexibility status the most. Therefore, we include these firms as part of the FF sample of companies and re-estimate our baseline model. Results in Table 5, column (5) are similar to those in Table 4.

Predicted Market-to-Book Value. Our analysis uses Sales Growth instead of Market-to-Book Value $(M T B V)$ as a proxy for growth opportunities, as our sample includes mostly privately held companies. A well-known problem in the investment literature is related to measurement of firm growth opportunities, which should be measured by the increase in firm value given an increment in the capital stock. If Sales Growth fails to properly measure a firm's growth opportunities, then the proxy of cash flow in our investment regressions may partly capture the growth opportunities as well. Consequently, the interpretation of previous results and the impact of FF status may be biased. As a further robustness test, we thus compute Predicted MTBV, largely following Campello and Graham (2013) and Mortal and Reisel (2013). This 
measure should capture a firm's growth opportunities, as explained by the firm's fundamentals, that are considered more informative in explaining investment decisions than market values. ${ }^{7}$ We replace Sales Growth with the new proxy for growth opportunities in the baseline investment model (1). Results are reported in Table 5, column (6). FF status still has a significant economic impact, qualitatively similar to those estimated in Table 4.

\section{[INSERT TABLE 5 HERE]}

\subsubsection{Strategic policy or credit rationing?}

A further possible criticism relates to interpretation of the conservative leverage policy. The low leverage level of FF firms may be explained via debt supply, rather than demand. In other words, those firms that we identify as FF firms could simply be firms that are rationed by lenders in the external capital markets, rather than firms that choose a conservative leverage strategy to accumulate debt spare capacity. If the debt supply explanation held, then it would be difficult to explain how, after a certain number of years of low leverage, our FF firms seem systematically to be able to invest significantly more than others. Nonetheless, we undertake four different types of test to investigate this potential alternative interpretation. First, we look at several firm characteristics during the years of conservative leverage policy that eventually

\footnotetext{
${ }^{7}$ We use market values and accounting data from the Worldscope database for all public companies of the countries included in our sample. For each public company and each year, we build a measure of MTBV as the ratio of the sum of total assets, market value minus common equity minus deferred taxes to total assets. For each country, we then regress MTBV on a number of variables considered in the literature as likely sources of information about the marginal product of capital: earnings, sales growth, net income before extraordinary items, and capital investment. We include both contemporaneous and lagged values of all these variables, with the exception of capital investment. We further complement firm-level information with variables that proxy industry conditions: contemporaneous and lagged industry sales growth and lagged industry capital investment. We obtain a vector of estimated coefficients for each country in our sample. Finally, we use these coefficients to construct the Predicted MTBV for each firm in our sample, both public and private.
} 
lead a firm to be classified as FF ("accumulation period") and we compare them with those of Not FF companies. As discussed in Section 2.2, we use at least three years of consecutive LL policy to define a company as financially flexible. Table 6, Panel A shows that during the accumulation period, FF firms are larger, more mature, more profitable, and have larger cash reserves than Not FF companies. Although not conclusive, this evidence may suggest that the conservative leverage policy of FF firms during the accumulation period may not be driven by limited access to credit markets.

To further corroborate our demand explanation, we use an indicator of financial constraints constructed by the European Central Bank (ECB) based on firms that participated in the Survey on Access to Finance of Enterprises (SAFE) from 2010 to 2013. This indicator covers all our sample countries except the UK. Construction of the SAFE indicator involves several steps. Based on the information included in the SAFE survey, the ECB provides both the estimates of the probability of a firm facing financial constraints and the thresholds of the SAFE score to identify credit-constrained firms in each country. In particular, financially constrained firms are those with a SAFE score value greater than the threshold of the country where the firm is headquartered. Therefore, the SAFE indicator is a binary dummy equal to 1 for financially constrained firms, and zero otherwise. (Please refer to Ferrando et al., 2015, for further details on the methodology). The idea here is to determine whether, during the accumulation period, FF firms are classified as financially constrained more often than Not FF firms. The last row in Panel A of Table 6 shows that, overall, only a small proportion of firms is classified as constrained by the SAFE indicator. However, the proportion of FF firms classified as constrained according to this measure is significantly lower than that for Not FF firms $(2.479 \%$ vs. $4.753 \%, p$-value $<0.001)$.

[INSERT TABLE 6 HERE] 
Second, we argue that if $F F$ status is a strategic choice rather than the inability of firms to raise further debt, then firms assigned to the FF group should not invest less than Not FF firms of similar characteristics during the accumulation period. Since the figures in Table 6 show that FF and Not FF firms are different for several observable characteristics, we use a propensity score matching procedure (Rosenbaum and Rubin, 1983) to identify a control sample of Not FF firms that exhibit no observable differences in characteristics relative to the FF firms during the accumulation period. Thus, each pair of matched firms is virtually indistinguishable from one another except for one key characteristic: investment level. To implement this methodology, we first calculate the probability (i.e., the propensity score) of a firm being assigned to the FF group. We calculate this probability as a function of all firm-level characteristics included in the leverage model. More specifically, in Panel B of Table 6, the propensity score is estimated within a country-industry-year category, as a function of sales growth, the natural log of total assets, asset tangibility, profitability, non-debt tax shield proxy, taxes, and cash holdings. To ensure that the firms in the control sample are sufficiently similar to the FF firms, we require that the maximum difference between the propensity score of an FF firm and that of its matching (Not FF) peer does not exceed $0.1 \%$ in absolute value. Comparison of investment levels between the two groups reveals that FF firms invest similarly to the other companies during the accumulation period.

Third, in the leverage regressions, we include variables that measure the extent of rationing to which a firm is likely to be exposed when raising its leverage. Previous studies indicate bond market access as a reasonable supply side factor (Faulkender and Petersen, 2006). We therefore exploit the heterogeneity of our sample and use the firm's listing status as a proxy for being able to access the bond market. We augment the leverage model with a dummy Public, equal to 1 if the company is publicly traded and zero otherwise. The idea here is that publicly traded firms have better access to external capital markets (bond markets in 
particular) and, therefore, are less likely to be rationed. To the extent that this proxy helps us to control for supply side factors, estimates of deviations from target leverage should capture only a conservative leverage strategy. From the estimates of the new augmented leverage model, we calculate a new FF dummy. Table 7, Panel A reports estimates from the investment model (1) with the new FF3 dummy (column 1). Results are in line with those in the baseline regressions. More importantly, the overall economic impact of FF status has not changed from that shown in Table 4, column (1). As a further test, we estimate separate leverage models for public and private companies. Again, from the estimates of the separate leverage models, we compute a new FF dummy. Results reported in column (2) corroborate our previous findings.

Fourth, we inspect the behavior of FF firms in terms of both investment and financial decisions around the time $t$ at which they are assigned FF status. Table 7, Panel B shows that FF firms do indeed experience an important increase in investment. In particular, this table shows that, between $t-2$ and $t$, the average change in investment of FF firms (Adjusted Investment) is well above the industry mean. Further, it shows that FF firms are not only able to invest more than their competitors, but they are also able to make (industry adjusted) abnormal investments. These are capital expenditures that are larger in value than the norm in the firm's life. We define a proxy for Normal Investment Activity by calculating the average value of industry-adjusted investments $\left(A d j I_{i t}\right)$ over five-year periods, but excluding the central year $\left(N I A_{i t}=\frac{A d j I_{\mathrm{t}-2}+A d j I_{\mathrm{t}-\mathrm{-}-1}+A d j I_{\mathrm{t}, \mathrm{t}+1}+A d j I_{\mathrm{t}+\mathrm{t} 2}}{4}\right)$. Then, we identify an instance of abnormal investment if the industry-adjusted investment at time $t$ is at least twice the Normal Investment Activity $\left(\operatorname{AdjI}_{, \mathrm{t}}>2 N I A_{i t}\right)$. Table 7, Panel B shows a significant increase in the level of investment of FF firms at time $t$ when we take into account both the competitors' investments and the normal pattern of investment by FF firms. Further, it reports that the proportion of FF firms that undertake abnormal investments is higher at time $t$, that is, after a certain period of conservative leverage policy. Turning to the financing decision, we observe that FF firms finance these 
investments by significantly increasing their total borrowing between $t$ - 2 and $t$ above the average level of leverage of their competitors (Adjusted Leverage). More importantly, their (industry adjusted) leverage is at its highest level when companies are identified as financially flexible. Altogether, this evidence further supports the idea that FF firms use their preserved borrowing power through a conservative leverage policy and are able to exercise better growth options in the future.

\section{[INSERT TABLE 7 HERE]}

\subsubsection{Cash holding policy}

Firms may achieve FF also in different ways from the low-leverage mechanism we propose. For instance, they may accumulate more cash (i.e., Denis and Sibilkov, 2010; Arslan-Ayaydin et al., 2014). This is the reason that, in all our specifications, we include cash holding as a determinant of leverage. Thus, our results are generated from a measure of FF that already controls for the cash position of the firm. Nonetheless, to further verify whether our results are affected by the role of cash holding, we run two tests.

First, we replace Leverage with Leverage net of Cash, defined as the ratio of the difference between total debt and cash to total assets, in line with Bates et al. (2009). We then estimate again both the leverage and the investment model (1). Table 8, column (1) reports the results. The FF3 dummy and the interaction term have the expected signs and are statistically significant. More importantly, we still find a significant economic impact from FF status.

Second, we control for the possibility that cash holding may be an integral part of the flexibility policy, following an approach similar in spirit to Arslan-Ayaydin et al. (2014). We re-estimate the leverage model excluding Cash and re-calculate the low-leverage state as in the baseline model. However, we define a firm as financially flexible if: 1) the firm is in a lowleverage state for a minimum number of consecutive years; and 2) the firm shows above average, industry-adjusted cash levels in the same years. Finally, we re-estimate the investment 
model. Table 8, column (2) shows similar results to the previous findings. However, note that the overall economic impact here is significantly lower than the baseline estimations; after at least three years of both conservative leverage policy and high cash holding policy, a company with average cash flow is able to increase its average investment only by about $7 \%$ compared to about $23 \%$ in Table 4 . This seems to support and further expand the survey evidence of Lins $e t$ al. (2010), which shows that companies prefer to use non-operational (excess) cash to hedge against future cash flow shocks in bad times, while they seem to use debt-like instruments, for example, credit lines, to exploit future investment opportunities. This may suggest that financial flexibility attained through leverage policies is more suited to capital expenditure policies than financial flexibility attained through cash holding.

\section{[INSERT TABLE 8 HERE]}

\subsubsection{Agency costs of equity}

Finally, we control for potential agency costs of equity. Previous studies suggest that managers may prefer suboptimal levels of leverage, that is, lower debt ratios, as a consequence of their lack of diversification. For instance, Lang et al. (1996) show that the relation between low leverage and high investment exists only in companies with poor growth opportunities, where free cash flow issues may be stronger and managers invest when they should not. However, managers may also use high leverage instrumentally, to reduce the risk of takeover (Berger $e t$ al., 1997), or to pursue empire-building projects (Zwiebel, 1996). If this is true, then the main determinant of both conservative leverage and higher investment in our results may be managerial entrenchment, rather than financial flexibility. We believe that this potential

criticism has little relevance to our sample, as most of our companies are privately held and therefore are less likely to suffer equity-related agency costs (Ang et al., 2000). In fact, Faccio et al. (2011) report that the average ownership of the largest ultimate shareholder in a large 
sample of European private and public companies over the period 1999-2007 is more than $63 \%$, where almost $30 \%$ of companies are wholly owned. Therefore, conflicts of interest between managers and shareholders are less likely to arise among companies in our sample. Nonetheless, to rule out the possibility of an agency cost explanation, we proceed as follows. We compute the fitted values of debt from the leverage model, augmented by a measure of equity agency costs to clean the residuals from this possible source of omitted variable bias. To measure equity agency costs, we use two alternative proxies separately: 1) the cash flow rights of the ultimate largest shareholder (when available) as in Faccio et al. (2011); and 2) the ratio of annual sales to total assets as in Ang et al. (2000). From the estimates of the two new augmented leverage models, we calculate the new FF dummies. Panel A in Table 9 reports the estimates from the investment model (1) with the new FF3 dummies. The results mirror those in the baseline regressions and the economic impact of FF status is qualitatively similar to that in Table 4, column (1).

\section{[INSERT TABLE 9 HERE]}

As a further test, we examine the impact of financial flexibility on operating performance. This allows us to investigate whether the investment increase due to financial flexibility is indeed good for shareholders. Panel B, Table 9 shows the changes in profitability following acquisition of FF status and following creation of abnormal investment. Companies appear to experience an increase in profitability of more than $6.4 \%$ after FF status is acquired (from $t-1$ to $t+2$ ); however, more importantly, they are able to generate a larger increase of about $20 \%$ in operating performance within two years from the time of their abnormal investment. 


\section{Value of financial flexibility and expected asymmetric information and contracting problems}

Once we show that the value of being financially flexible is indeed directly related to the ability of firms to invest more, we investigate whether the theoretical prediction postulated by Gamba and Triantis (2008) is supported by empirical evidence. That is, for financially flexible firms that face lower costs of external financing, the premium at which they are traded should be smaller than that of other firms with high levels of financial flexibility that face higher cost of external financing. In our setting, we explore whether, for firms with higher expected asymmetric information and contracting problems, the degree of financial flexibility is more valuable (i.e., higher capital expenditure) than for firms that are less exposed to capital market frictions. We employ two sets of variables to identify these firms: those pertaining to firm characteristics and those pertaining to characteristics of the institutional setting in which the firm operates.

\subsection{Firm characteristics}

First, we use firm characteristics often employed in the literature as proxies for informational asymmetries and contracting problems that may prevent companies from accessing external capital markets (e.g., Cleary, 2006). Thanks to the heterogeneity of firms included in our database, we create subsamples based on firm listing status (privately held vs. publicly traded companies) and on firm size and age. Private companies (e.g., Brav, 2009; Saunders and Steffen, 2011), small-sized (Berger and Udell, 1998 and 2006), and young firms (e.g., Rauh, 2006; Fee et al., 2009) face different and often more severe financing problems than do public, large, and more mature companies. More recently, Hadlock and Pierce (2010) focus on the importance of the combination of firm size and age as predictors of potential asymmetric and contracting problems. Therefore, we expect private, small, and young firms to value FF status 
more than other firms. In other words, private, small and young firms that are financially flexible should invest more than others.

Table 10 reports the results of the investment model for the subsamples of private and public companies. We note a remarkable difference between private and public firms in terms of both sensitivity of investment to cash flow and growth opportunities. Private firms show higher investment-cash flow sensitivity than do public firms (the estimated coefficient of Cash Flow is almost seven times larger), consistent with the hypothesis that these firms face more capital market frictions and, consequently, their capital expenditure depends more on internal funds. Further, private firms seem more responsive to changes in growth opportunities than public firms; the coefficient of Sales Growth is indeed higher. More importantly, the different impact of FF status across the two subsamples points to the different financing strategies pursued by private and public firms. Indeed, the estimated FF dummy is significantly different across the two subsamples ( $p$-value less than 0.001 ). The value of a conservative leverage policy seems higher for private than for public firms. Indeed, for an average private firm, a conservative leverage policy for at least three years implies an increase in its capital expenditure of $22.6 \%$ (column 1), while for an average public firm the increase is only $6.9 \%$ (column 2). Results are similar when we consider a more stringent criterion for FF status for both subsamples of firms (columns 3 and 4).

\section{[INSERT TABLE 10 HERE]}

Table 11 shows the results of the investment regressions when we split the sample according to size, age, and a combination of these two firm characteristics. As expected, investment-cash flow sensitivity decreases with size, while growth opportunities play a more important role for small-sized and young firms than they do for large firms. More importantly, financial flexibility is more valued by small- and medium-sized firms as well as by young firms. The coefficient of the FF dummy significantly decreases with size and age ( $p$-value less 
than 0.001). Indeed, for an average small firm, being financially flexible implies an increase in capital expenditure of $16.1 \%$ (column 1), while for an average large company the increase is about $15.6 \%$ (column 3). The difference is even more striking when we examine firm age; an average young FF firm is able to increase its investment by $25.7 \%$ after (at least) three years of conservative leverage policy, while the equivalent figure for a mature company is only about 9\%. These findings are also confirmed for the subsample of small and young firms that seem able to increase their investment by about $20 \%$ if they are financially flexible (column 6), while large and mature flexible firms increase it by only $7 \%$ (column 7).

These tests also provide further insight on the impact of a conservative leverage policy within each subsample of firms. Overall, firms with similar size (age) that follow a conservative leverage policy are able to increase their capital expenditure more than those that do not follow such a strategy. They are also able to reduce their exposure to capital market imperfections, by reducing their dependence on internal sources of finance. This result is particularly important for small and young firms.

\section{[INSERT TABLE 11 HERE]}

\subsection{Institutional setting}

To further capture the potential asymmetric information and contracting problems firms are likely to face, we examine the institutional setting of the countries in which companies operate. An extensive literature points out that legal protection can substantially affect the ability of firms to raise external finance (e.g., La Porta et al., 1997). In particular, the protection provided by legal institutions is a predictor of the costs of external financing (Almeida et al., 2011). This in turn affects corporate financial and investment decisions (Love, 2003; Mclean et al., 2012; Mortal and Reisel, 2013).

This implies that financial flexibility should be more valuable in countries where legal protection is poorer and firms' asymmetric information and contracting problems are expected 
to be more intense. Therefore, in these countries, FF firms should be able to invest more than they do in other countries. To test this hypothesis, we use two indices to proxy credit accessibility and investor protection.

The first index, Credit Access Index, measures the legal rights of borrowers and lenders with respect to secured transactions and the sharing of credit information, as provided by the World Bank-Doing Business Project, which includes four indices: 1) The strength of legal rights index (which measures the degree to which collateral and bankruptcy laws protect the rights of borrowers and lenders and thus facilitate lending). This index ranges from 0 to 10 , with higher scores indicating that collateral and bankruptcy laws are better designed to expand access to credit). 2) The depth of credit information index (which measures rules and practices affecting the coverage, scope, and accessibility of credit information available through either a public credit registry or a private credit bureau). This index ranges from 0 to 6 , with higher values indicating the availability of more credit information, from either a public credit registry or a private credit bureau, to facilitate lending decisions. 3) The public credit registry index. 4) The private credit bureau index. The latter two indexes measure the coverage of public credit registries and private credit bureaus, respectively, in each country. These two indices range from 1 to 5, with higher values indicating higher numbers of individuals and firms listed in a public credit registry (or private credit bureau), with information on their borrowing history for the preceding five years. ${ }^{8}$ For each country, we sum the four index scores to obtain a final composite index of credit accessibility. The resulting index should range from 0 to 26 , with higher values indicating higher credit access. The more that collateral and bankruptcy laws

\footnotetext{
${ }^{8}$ http://www.doingbusiness.org/methodology/getting-credit. Both the public credit registry and private credit bureau coverage indicators are provided by the World Bank as a percentage of the adult population. To make these two indicators comparable to the strength of legal rights and the depth of credit information indicators, we assign a number from 1 to 5 to each quintile of the distribution of each of these indicators.
} 
protect the rights of borrowers and lenders and the better the access to credit information, the more that lending is promoted.

The second index, Anti-Self-Dealing Index, measures the strength of minority shareholder protection against directors' misuse of corporate assets. Following Djankov et al. (2008), the Anti-Self-Dealing Index is the average of: 1) extent of disclosure index; 2) extent of director liability index; and 3) ease of shareholder suits index. This composite index should range from 0 to 10 , with higher values indicating more investor protection. Recent crosscountry studies show that stronger minority shareholder protection and better disclosure are beneficial not only to shareholders, but also to creditors, as evidenced by decreased costs of debt and easier access to debt markets (e.g., Miller and Puthenpurackal, 2002; Harvey et al., 2004; Miller and Reisel, 2012). Therefore, the higher the Anti-Self-Dealing Index, the better the conditions to promote lending.

Both indices are available from 2006. We use their 2006 values across our entire sample period. It is reasonable to assume that the overall composite indices have not changed greatly over time. ${ }^{9}$ In fact, these indices do not vary considerably after 2006.

We divide the sample countries based on the median value of each composite index. Countries with above-median credit accessibility are Belgium, Germany, Netherlands, and United Kingdom, while those with above-median investor protection are Belgium, Portugal, and United Kingdom. Finally, we estimate again investment model (1) on each subsample of countries and compare the impact of FF status on firm investment ability. Table 12, columns 14 report the results on the subsamples based on the credit accessibility index, while columns 5-

\footnotetext{
${ }^{9}$ In fact, these indices do not vary considerably after 2006. Further, Djankov et al. (2007) find only 32 changes in their Creditor Rights variable in the period 1978-2004, across 133 countries, and of these, only one change is relevant to one of our countries: Spain improved its Creditor Rights score by one notch in 2004. This does not affect our classification though.
} 
8 report those based on the investor protection index. We find that investment is more sensitive to cash flow in countries with overall lower legal protection, in line with Mclean et al. (2012). Most importantly, the findings suggest that FF firms are able to invest more than others, and this effect is significantly larger in those countries where legal protections are lower ( $p$-value less than 0.001). The economic value of being financially flexible is also important. Companies that pursue a conservative leverage policy for at least three years (FF3) are able to increase their average investment by almost $22.7 \%$ in countries with more limited credit accessibility, while in countries with better credit accessibility FF firms increase their average investment by only $7.9 \%$ (columns 1 and 2, respectively). We find similar differences when we use the investor protection index.

\section{[INSERT TABLE 12 HERE]}

To further test these findings, we run the investment regressions individually for each country in the sample. This allows us to have different estimated coefficients for the FF3 dummy for each country separately. Figure 1 shows the plot of the estimated coefficients of the FF3 dummy for each country with respect to each country's Credit Access Index (Panel A) and Investor Protection Index (Panel B). In this way, we test whether the previous indices are indeed correlated with the extent of the FF3 dummy. In other words, countries with better credit access (investor protection) appear to feature lower estimated FF3 coefficients. This confirms our previous conjecture that the value of being financially flexible is stronger in countries with more limited credit accessibility (investor protection). ${ }^{10}$

\footnotetext{
${ }^{10}$ As an alternative test, we separate the euro area countries from the UK, re-run the same investment model (1) as above, and compare the impact of FF status between the two subsamples. Since the introduction of the euro in 1999, capital markets in the euro area countries have progressively developed and integrated with each other. Nonetheless, their overall size is still smaller than the UK financial sector (European Central Bank, 2012). Untabulated results show that, consistent with our expectations, financial flexibility seems more important for euro area companies than for the UK.
} 


\section{[INSERT FIGURE 1 HERE]}

\subsection{Liquidity shock}

Our previous results strongly suggest that spare borrowing capacity helps firms to invest relatively more than others, in the presence of asymmetric information and contracting problems. This implies that FF status may be more valuable when an exogenous shock in the capital markets makes external financing even less accessible. The recent financial crisis offers a natural experiment to investigate whether FF companies invest more even in the presence of a severe exogenous liquidity shock. If our hypothesis is correct, we expect FF firms to display a lower proportional reduction in investment and a lower investment sensitivity to cash flow than other companies during the crisis.

To test this hypothesis, we exploit the last eight years of our sample, 2003 to 2010. In particular, we focus on companies in 2006 , the year before the start of the financial crisis, and distinguish those that are financially flexible from those that are not. As in our main analysis, to classify a firm as financially flexible, we require it to have an LL policy for at least three consecutive years (FF3). As a robustness test, we also require at least five consecutive years of LL policy (FF5). The final subsample counts 219,953 firm year observations. We then employ two different tests.

First, we look at trends in investment levels and financing choices before and during the crisis. In more detail, we compare the average investment levels of FF and Not FF firms before and during the crisis. We then calculate the average of the investment level for firm $i$ before (during) the crisis over the 2003-2006 (2007-2010) period. Finally, we compare the levels of investment of (Not-) FF firms before and during the crisis, and then we compare these changes between the two subsamples. We first note that, in line with our hypothesis, during the financial crisis, all firms invested on average less than in the four preceding years. In fact, average capital expenditure decreased from 0.384 to 0.254 (Table 13 Panel A). More importantly, FF 
firms seem to be less affected by the crisis than Not FF firms. For instance, the change in average investment between the two sub-periods (2003-2006 and 2007-2010) for FF3 firms is equal to -0.068 , while for the others it is about -0.144 . Further, the difference between the change in investment for FF3 firms and the change in investment for Not FF firms (e.g., (0.268 $-0.336)-(0.250-0.394)=0.076)$ is significant, with a $p$-value $<0.001$. To further corroborate this evidence, we compare the investment levels of FF firms with those of a matched sample of Not FF companies. ${ }^{11}$ Results show again that FF firms experience a significantly smaller decrease in investment level than similar Not FF companies (e.g., $(0.268-0.336)-(0.255-$ $0.393)=0.07, p$-value $<0.001)$.

In a similar way, we investigate the patterns of financing choices, that is, leverage and cash holding. Table 13, Panel B shows that during the crisis, the leverage level increases significantly more for FF firms. For instance, the change in leverage for FF firms is equal to 0.084, while for (matched) Not FF firms it is only (0.012) 0.008 , both significant with a $p$-value $<0.001$. Interestingly, the change in cash holding is not as large as the change in leverage for all companies and it is essentially equivalent across all groups. This further supports the evidence in Table 8 that, at least in our sample of European firms, financial flexibility attained through a conservative leverage policy seems effective in increasing a firm's ability to invest, and this further complements the evidence on conservative leverage policy in the US from de Jong et al. (2012).

Second, we estimate a simple q-model of investment for the years of the financial crisis (2007-2010) on data from the three subsamples as defined above: firms identified as financially flexible in 2006; firms identified as not financially flexible in the same year; and

\footnotetext{
${ }^{11}$ As above, we employ a very stringent propensity score matching procedure to find a group of Not FF firms with similar observable characteristics to FF firms in 2006. We thank an anonymous referee for suggesting this test.
} 
firms classified as not financially flexible matched with financially flexible companies. The idea here is to determine whether firms that acquired the flexibility status before the crisis are less exposed to capital market imperfections. As reported in Table 13, Panel C, FF firms do indeed show significantly lower investment sensitivity to cash flow than both Not FF and matched Not FF companies (0.305 versus 0.371 and 0.407 for FF3, Not FF, and matched Not FF firms, respectively, $p$-value $<0.001)$.

Overall these results seem to further corroborate the hypothesis that companies with more spare debt capacity appear better equipped to deal with shocks in the supply of capital. Our results complement US studies that show that the recent financial crisis has more severely hampered the investment of non-financial companies with high net short-term debt (Almeida et al., 2012) or low cash reserves (Duchin et al., 2010).

[INSERT TABLE 13 HERE]

\section{Conclusions}

We provide novel evidence that the value of financial flexibility is higher for private, smaller and younger firms. A private (small, young) FF firm is able to increase its average investment by about $22.6 \%(16.1 \%, 25.7 \%)$ after at least three years of conservative leverage policy. Further, firms in countries with poorer legal protections and less developed capital markets are more likely to benefit from pursuing financial flexibility through a conservative leverage strategy. For instance, FF firms in countries with poorer access to credit seem to increase their capital expenditure by an average of $22.7 \%$. Finally, we provide evidence that spare borrowing capacity helps firms to divest less than others in the event of exogenous liquidity shocks in the capital markets, such as during the very recent financial crisis. Firms classified as FF before 2007 were able to reduce their average investment by about $7.6 \%$ less than other companies during the 2007-2010 period. 
This paper holds important policy implications. SMEs are a keystone of the euro area economy, as evidenced by the fact that they represent the vast majority of firms $(99.8 \%)$ and account for a large share of employment and value added. ${ }^{12}$ In 2008, the European Commission adopted the Small Business Act for Europe (SBA), which puts into place a comprehensive SME policy framework for the EU and its member states. Meanwhile, access to finance has deteriorated in several European countries, as a result of higher interest rates and greater demand for collateral. This has sparked an intense debate on revamping efforts to enable SMEs greater and easier access to finance. The initiative of the European Commission for the creation of a true capital markets union, launched at the beginning of 2015 , is an example of the intense debate over possible policy measures aimed at increasing lending to the economy via direct support to banks, to stabilize bank lending to SMEs, and/or via alternative sources of SME financing. ${ }^{13}$ One recurrent theme in these initiatives is the lack of reliable information about SMEs and the related difficulty for potential investors to evaluate their credit worthiness. In this light, our analysis may provide crucial evidence on how companies proactively manage the sustainability of their operations. In fact, our findings on the impact of financial flexibility attained through conservative leverage policy shed more light on the mechanisms through which SMEs tackle potential financial frictions that may otherwise hamper their growth.

Further, there is evidence that the surge in leverage in Europe before the crisis sowed the seeds of the financial crisis and has had a significant effect on the nature, severity, and persistence of the downturn at both macro and micro levels. ${ }^{14}$ A recent study by the ECB

\footnotetext{
${ }^{12}$ http://ec.europa.eu/growth/smes/business-friendly-environment/performance-review/files/supportingdocuments/2014/annual-report-smes-2014_en.pdf.

13 See EC (2013), “Green Paper on Capital Markets Union”, http://eur-lex.europa.eu/legalcontent/EN/TXT/PDF/?uri=COM:2015:63:FIN\&from=EN.

${ }^{14}$ See Reinhart and Rogoff (2011), Jorda et al. (2011), and Kremp and Sevestre (2013).
} 
(2013) shows that the average leverage of firms that initially had zero or low levels of debt in 2008 has continued to increase during the crisis; on the other hand, firms with initially high levels of leverage began a deleveraging process almost immediately and have significantly reduced their investment during the crisis. The pattern we observe among financially flexible firms during the crisis is consistent with and complements this evidence. Those companies that accumulated spare debt capacity through a conservative leverage policy for a number of years before the crisis are those that are able to raise external financing and undertake investments when a growth opportunity comes along, despite a deteriorated macroeconomic outlook. Our results, therefore, add to the complex assessment of the benefits of deleveraging, and show that an aggregate deleveraging pattern is compatible with one of increasing leverage at a particular point in time for firms categorized as financially flexible. 


\section{References}

Almeida, H., Campello, M., Laranjeira, B. and Weisbenner, S. 'Corporate debt maturity and the real effects of the 2007 credit crisis', Critical Finance Review, Vol. 4(4), 2012, pp. 358.

Almeida, H., Campello, M. and Weisbach, M. S., 'Corporate financial and investment policies when future financing is not frictionless', Journal of Corporate Finance, Vol. 17(3), 2011, pp. 675-93.

Alti, A., 'How sensitive is investment to cash flow when financing is frictionless?', The Journal of Finance, Vol. 58(2), 2003, pp. 707-22.

Ang, J. and Smedema, A., 'Financial flexibility: Do firms prepare for recession?', Journal of Corporate Finance, Vol. 17(3), 2011, pp. 774-87.

Ang, J. S., Cole, R. A. and Lin, J. W., 'Agency costs and ownership structure', Journal of Finance, Vol. 55(1), Feb, 2000, pp. 81-106.

Arslan-Ayaydin, Ö., Florackis, C. and Ozkan, A., 'Financial flexibility, corporate investment and performance: Evidence from financial crises', Review of Quantitative Finance and Accounting, Vol. 42(2), 2014, pp. 211-50.

Asker, J., Farre-Mensa, J. and Ljungqvist, A., 'Corporate investment and stock market listing: A Puzzle?', Review of Financial Studies, forthcoming, 2014.

Bancel, F. and Mittoo, U. R., 'Cross-country determinants of capital structure choice: A survey of European firms', Financial Management, Vol. 33(4), 2004, pp. 103-32.

Bancel, F. and Mittoo, U. R., 'Financial flexibility and the impact of the global financial crisis’, International Journal of Managerial Finance, Vol. 7(2), 2011, pp. 179-216.

Bates, T. W., Kahle, K. M. and Stulz, R. M., 'Why do U.S. firms hold so much more cash than they used to?', The Journal of Finance, Vol. 64(5), 2009, pp. 1985-2021. 
Becker, B. and Sivadasan, J., 'The effect of financial development on the investment-cash flow relationship: Cross-country evidence from Europe', The BE Journal of Economic Analysis \& Policy, Vol. 10(1), 2010, pp. 1-43.

Berger, A. N. and Udell, G. F., 'The economics of small business finance: The roles of private equity and debt markets in the financial growth cycle', Journal of Banking \& Finance, Vol. 22(6-8), 1998, pp. 613-73.

Berger, A. N. and Udell, G. F., 'A more complete conceptual framework for SME finance', Journal of Banking \& Finance, Vol. 30(11), 2006, pp. 2945-66.

Berger, P. G., Ofek, E. and Yermack, D. L., 'Managerial entrenchment and capital structure decisions', Journal of Finance, Vol. 52(4), 1997, pp. 1411-38.

Bessler, W., Drobetz, W., Haller, R. and Meier, I., 'The international zero-leverage phenomenon', Journal of Corporate Finance, Vol. 23(12), 2013, pp. 196-221.

Bond, S., Elston, J. A., Mairesse, J. and Mulkay, B., 'Financial factors and investment in Belgium, France, Germany, and the United Kingdom: A comparison using company panel data', Review of Economics and Statistics, Vol. 85(1), 2003, pp. 153-65.

Brav, O., 'Access to capital, capital structure, and the funding of the firm', The Journal of Finance, Vol. 64(1), 2009, pp. 263-308.

Brounen, D., de Jong, A. and Koedijk, K., 'Capital structure policies in Europe: Survey evidence', Journal of Banking \& Finance, Vol. 30(5), 2006, pp. 1409-42.

Brown, J. R. and Petersen, B. C., 'Why has the investment-cash flow sensitivity declined so sharply? Rising R\&D and equity market developments', Journal of Banking \& Finance, Vol. 33(5), 2009, pp. 971-84.

Brown, J. R. and Petersen, B. C., 'Cash holdings and R\&D smoothing', Journal of Corporate Finance, Vol. 17(3), 2011, pp. 694-709. 
Campello, M. and Graham, J. R., 'Do stock prices influence corporate decisions? Evidence from the technology bubble', Journal of Financial Economics, Vol. 107(1), 2013, pp. 89110.

Cleary, S., 'The relationship between firm investment and financial status', The Journal of Finance, Vol. 54(2), 1999, pp. 673-92.

Cleary, S., 'International corporate investment and the relationships between financial constraint measures', Journal of Banking \& Finance, Vol. 30(5), 2006, pp. 1559-80.

de Jong, A., Verbeek, M. and Verwijmeren, P., 'Does financial flexibility reduce investment distortions?', Journal of Financial Research, Vol. 35(2), 2012, pp. 243-59.

DeAngelo, H. and DeAngelo, L., 'Capital structure, payout policy, and financial flexibility', SSRN Working Paper Series 916093, 2007.

Denis, D. J., 'Financial flexibility and corporate liquidity', Journal of Corporate Finance, Vol. 17(3), 2011, pp. 667-74.

Denis, D. J. and McKeon, S. B., 'Debt financing and financial flexibility evidence from proactive leverage increases', Review of Financial Studies, Vol. 25(6), 2012, pp. 1897 929.

Denis, D. J. and Sibilkov, V., 'Financial constraints, investment, and the value of cash holdings', Review of Financial Studies, Vol. 23(1), 2010, pp. 247-69.

Djankov, S., La Porta, R., Lopez-de-Silanes, F. and Shleifer, A., 'The law and economics of self-dealing', Journal of Financial Economics, Vol. 88(3), 2008, pp. 430-65.

Djankov, S., McLiesh, C. and Shleifer, A., 'Private credit in 129 countries', Journal of Financial Economics, Vol. 12(2), 2007, pp. 77-99.

Duchin, R., Ozbas, O. and Sensoy, B. A., 'Costly external finance, corporate investment, and the subprime mortgage credit crisis', Journal of Financial Economics, Vol. 97(3), 2010, pp. 418-35. 
ECB, 'Financial integration in Europe', Bulletin, 2012.

ECB, 'Corporate finance and economic activity in the euro area', Occasional Paper, Vol. $151,2013$.

Faccio, M., Marchica, M.-T. and Mura, R., 'Large shareholder diversification and corporate risk-taking', Review of Financial Studies, Vol. 24, 2011, pp. 3601-3641.

Faulkender, M., Flannery, M. J., Hankins, K. W. and Smith, J. M., 'Cash flows and leverage adjustments', Journal of Financial Economics, Vol. 103(3), 2012, pp. 632-46.

Faulkender, M. and Petersen, M. A., 'Does the source of capital affect capital structure?', Review of Financial Studies, Vol. 19(1), Spr, 2006, pp. 45-79.

Fazzari, S., Hubbard, R. G. and Petersen, B. C., 'Financing constraints and corporate investment', National Bureau of Economic Research Working Paper Series no.2387, 1987.

Fee, C. E., Hadlock, C. J. and Pierce, J. R., 'Investment, financing constraints, and internal capital markets: Evidence from the advertising expenditures of multinational firms', Review of Financial Studies, Vol. 22(6), 2009, pp. 2361-92.

Ferrando, A., Iudice, M., Altomonte, C., Blank, S., Felt, M. H., Meinen, P., Neugebauer, K., and Siedschlag, I., "Assessing the financial and financing conditions of firms in Europe: The financial module in CompNet", European Central Bank Working Paper Series no.1836, August, 2015.

Gamba, A. and Triantis, A., 'The value of financial flexibility', The Journal of Finance, Vol. 63(5), 2008, pp. 2263-96.

Gilje, E. and Taillard, J. P., 'Do public firms invest differently than private firms? Taking cues from the natural gas industry', SSRN Working Paper 2031614, 2013.

Graham, J. R. and Harvey, C. R., 'The theory and practice of corporate finance: Evidence from the field', Journal of Financial Economics, Vol. 60(2-3), 2001, pp. 187-243. 
Graham, J. R. and Harvey, C. R., 'The theory and practice of corporate finance: Evidence from the field', Journal of Financial Economics, Vol. 60(2), 2001, pp. 187-243.

Hadlock, C. J. and Pierce, J. R., 'New Evidence on measuring financial constraints: Moving beyond the KZ index', Review of Financial Studies, Vol. 23(5), 2010, pp. 1909-40.

Harvey, C. R., Lins, K. V. and Roper, A. H., 'The effect of capital structure when expected agency costs are extreme', Journal of Financial Economics, Vol. 74, 2004, 3-30.

Jorda, O., Schularick, M. and Taylor, A.M., 'Financial Crises, Credit Booms, and External Imbalances: 140 Years of Lessons', IMF Economic Review, Vol. 59, 2011, 340-378.

Kahl, M., Shivdasani, A. and Wang, Y., 'Short-Term debt as bridge financing: Evidence from the commercial paper market', The Journal of Finance, Vol. 70(1), 2015, 211-255.

Kalemli-Ozcan, S., Laeven, L. and Moreno, D., 'Debt Overhang in Europe: Evidence from Firm-Bank-Sovereign Linkages', mimeo, 2015.

Kremp, E. and Sevestre, P., 'Did the crisis induce credit rationing for French SMEs?', Journal of Banking \& Finance, Vol. 37(10, 2013, pp. 3757-72.

La Porta, R., Lopez-De-Silanes, F., Shleifer, A. and Vishny, R. W., 'Legal determinants of external finance', The Journal of Finance, Vol. 52(3), 1997, pp. 1131-50.

Lang, L., Ofek, E. and Stulz, R., 'Leverage, investment, and firm growth', Journal of Financial Economics, Vol. 40(1), 1996, pp. 3-29.

Lins, K. V., Servaes, H. and Tufano, P., 'What drives corporate liquidity? An international survey of cash holdings and lines of credit', Journal of Financial Economics, Vol. 98, 2010, pp. 160-176.

Love, I., 'Financial development and financing constraints: International evidence from the structural investment model', Review of Financial Studies, Vol. 16(3), 2003, pp. 765-91. 
Lyandres, E., Marchica, M.-T., Michaely, R. and Mura, R., 'Owners' portfolio diversification and firm investment: Evidence from private and public firms', SSRN Working Paper $2234195,2015$.

Marchica, M.-T. and Mura, R., 'Financial flexibility, investment ability, and firm value: Evidence from firms with spare debt capacity', Financial Management, Vol. 39(4), 2010, pp. 1339-65.

McLean, R. D., Zhang, T. and Zhao, M., 'Why does the law matter? Investor protection and its effects on investment, finance, and growth', The Journal of Finance, Vol. 67(1), 2012, pp. 313-50.

Miller, D. P., and J. Puthenpurackal, 'The costs, wealth effects, and determinants of international capital raising: Evidence from public Yankee bonds', Journal of Financial Intermediation, Vol. 11, 2002, 455-85.

Miller, D. P., and Reisel, N., 'Do country-level investor protections affect security-level contract design? Evidence from foreign bond covenants', Review of Financial Studies Vol. $25,2012,409-438$

Modigliani, F. and Miller, M. H., 'Corporate income taxes and the cost of capital: A correction', American Economic Review, Vol. 53(3), 1963, pp. 433-443.

Mortal, S. and Reisel, N., 'Capital allocation by public and private firms', Journal of Financial and Quantitative Analysis, Vol. 48(01), 2013, pp. 77-103.

Myers, S. C., 'The capital structure puzzle', The Journal of Finance, Vol. 39(3), 1984, pp. $575-92$.

Rapp, M. S., Schmid, T. and Urban, D., 'The value of financial flexibility and corporate financial policy', Journal of Corporate Finance, Vol. 29, 2014, pp. 288-302.

Rauh, J. D., 'Investment and financing constraints: Evidence from the funding of corporate pension plans', The Journal of Finance, Vol. 61(1), 2006, pp. 33-71. 
Reinhart, C. M. and Rogoff, K. S., 'From financial crash to debt crisis', American Economic Review, Vol. 101(5), 2011, pp. 1676-706.

Saunders, A. and Steffen, S., 'The costs of being private: Evidence from the loan market', Review of Financial Studies, Vol. 24(12), 2011, pp. 4091-122.

Schoubben, F. and Van Hulle, C., 'Stock listing and financial flexibility', Journal of Business Research, Vol. 64(5), 2011, pp. 483-89.

Sheen, A. W., 'Do public and private firms behave differently? An examination of investment in the chemical industry', Harvard Working Paper Series, 2011.

Strebulaev, I. A., and Yang, B., 'The mystery of zero-leverage firms' , Journal of Financial Economics, Vol. 109, 2013, 1-23.

Vismara, S., Paleari, S. and Ritter, J. R., 'Europe's second markets for small companies', European Financial Management, Vol. 18(3), 2012, 352-388.

Zwiebel, J., 'Dynamic capital structure under managerial entrenchment', American Economic Review, Vol. 86(5), 1996, pp. 1197-215. 
Table 1

\section{Sample Characteristics}

This table provides sample characteristics. The sample includes all non-financial firms (both publicly traded and privately held companies) in eight euro countries and the UK with accounting information for at least four years over the period 1993-2010.

\begin{tabular}{lccccc}
\hline & No. firms & No. obs. & \% Private & Size (€ mil) & Age \\
\hline Belgium & 10,631 & 111,449 & $99.29 \%$ & 43.91 & 25.34 \\
Finland & 17,623 & 141,487 & $99.37 \%$ & 12.60 & 16.32 \\
France & 190,990 & $1,641,927$ & $99.77 \%$ & 8.22 & 16.02 \\
Germany & 6,927 & 43,393 & $92.90 \%$ & 316.10 & 34.57 \\
Italy & 148,016 & $1,193,518$ & $99.84 \%$ & 10.17 & 17.77 \\
Netherlands & 2,357 & 17,909 & $92.72 \%$ & 283.44 & 34.31 \\
Portugal & 45,114 & 222,202 & $99.70 \%$ & 6.49 & 17.34 \\
Spain & 244,450 & $2,048,918$ & $99.91 \%$ & 5.06 & 12.16 \\
UK & 19,585 & 101,422 & $99.12 \%$ & 28.97 & 21.11 \\
\hline Total & 685,693 & $5,522,225$ & & & \\
Sample mean & & & $99.68 \%$ & 13.31 & 15.88 \\
\hline \hline
\end{tabular}

Table 2

Summary Statistics

This table reports summary statistics of the variables included in the investment model. All variables are winsorized at the $1^{\text {st }}$ and $99^{\text {th }}$ percentiles of their distribution within each country. Please refer to Appendix A for definitions of all variables.

\begin{tabular}{lccccc}
\hline \hline & Mean & Median & St. Dev & Min & Max \\
\hline$\frac{\Delta \text { Gross PPE }_{j, t}}{K_{i, t}}$ & 0.426 & 0.123 & 1.015 & -0.309 & 6.485 \\
$\frac{\text { Cash Flow }_{i, t-1}}{K_{i, t-1}}$ & 0.595 & 0.298 & 0.853 & -1.084 & 3.256 \\
Sales Growth & 0.230 & 0.043 & 1.760 & -1.000 & 5.065 \\
\hline \hline
\end{tabular}


Table 3

\section{Financially Flexible Firms}

This table reports the percentage of financially flexible (FF) firms across the entire sample, by legal status, size, age, institutional settings and geographic subdivisions. To build the FF status indicator, we compare the fitted values from the leverage regressions in Appendix B with the actual values of Leverage for each firm each year. We define a firm as $L L$ (lower-levered) if the negative deviation between actual and predicted leverage is greater than 5\%.FF3, FF4, and $F F 5$ are dummies that take the value of 1 when we observe at least three, four, or five consecutive periods, respectively, in which the firm is classified as LL. Small, Medium, and Large firms are identified using the tertile distribution of the (logarithm of) total assets in each country each year. Young and Mature firms are defined on the bottom and top tertile of age distribution. Low (High) Credit Access Index is an indicator equal to 1 if the country where the firm operates has a below (above)-median value of the credit access index.

\begin{tabular}{lrccc}
\hline \hline & & $\boldsymbol{F F 3}$ & $\boldsymbol{F F 4}$ & $\boldsymbol{F F 5}$ \\
\hline All sample & & $31.22 \%$ & $20.71 \%$ & $13.84 \%$ \\
\hline Legal status & & & \\
& Private & $31.14 \%$ & $20.65 \%$ & $13.80 \%$ \\
& Public & $0.08 \%$ & $0.06 \%$ & $0.04 \%$ \\
\hline Size & & & \\
& Small & $14.68 \%$ & $8.73 \%$ & $5.32 \%$ \\
& Medium & $13.39 \%$ & $8.99 \%$ & $5.92 \%$ \\
& Large & $9.09 \%$ & $6.73 \%$ & $4.87 \%$ \\
\hline Age & & & \\
& Young & $20.44 \%$ & $12.19 \%$ & $7.01 \%$ \\
& Mature & $2.69 \%$ & $1.94 \%$ & $1.50 \%$ \\
\hline Institutional setting & & & \\
& & & & \\
& Low credit access index & $30.18 \%$ & $20.00 \%$ & $13.36 \%$ \\
High credit access index & $1.04 \%$ & $0.71 \%$ & $0.48 \%$ \\
Low anti-self-dealing index & $29.40 \%$ & $19.56 \%$ & $13.14 \%$ \\
High anti-self-dealing index & $1.82 \%$ & $1.15 \%$ & $0.70 \%$ \\
\hline \hline
\end{tabular}




\section{Table 4}

\section{Investment Model: Baseline Regressions}

This table presents GMM-DIFF results for the modified q-model of investment augmented by the financially flexible status dummies $(F F 3, F F 4$, and $F F 5)$ and the interaction between these dummies and Cash Flow. Please refer to Appendix A for definitions of all variables. We use suitable lags of all independent variables as well as year dummies as instruments. All regressions include firm and year fixed effects. $P$-values, adjusted for heteroskedasticity, are reported in brackets below the coefficients. *, ** and *** indicate statistical significance levels of $10 \%, 5 \%$ and $1 \%$, respectively.

\begin{tabular}{lccc}
\hline \hline & $\boldsymbol{F F 3}$ & $\boldsymbol{F F 4}$ & $\boldsymbol{F F 5}$ \\
\hline$\frac{\text { Gross } P P E_{i, t-1}}{K_{i, t-1}}$ & $0.020^{* * *}$ & $0.020^{* * *}$ & $0.020^{* * *}$ \\
$\frac{\text { Cash Flow }_{i, t-1}}{K_{i, t-1}}$ & {$[0.000]$} & {$[0.000]$} & {$[0.000]$} \\
& $0.470^{* * *}$ & $0.464^{* * *}$ & $0.460^{* * *}$ \\
Sales growth & {$[0.000]$} & {$[0.000]$} & {$[0.000]$} \\
& $0.226^{* * *}$ & $0.224^{* * *}$ & $0.220^{* * *}$ \\
FF dummy & {$[0.000]$} & {$[0.000]$} & {$[0.000]$} \\
& $0.139 * * *$ & $0.136^{* * *}$ & $0.129 * * *$ \\
Cash Flowi,t-1 X FF dummy & {$[0.000]$} & {$[0.000]$} & {$[0.000]$} \\
$K_{i, t-1}$ & $-0.072^{* * *}$ & $-0.068 * * *$ & $-0.050^{* * *}$ \\
\hline Firm year observations & {$[0.000]$} & {$[0.000]$} & {$[0.000]$} \\
No. of firms & $1,598,899$ & $1,598,899$ & $1,598,899$ \\
Firm fixed effects & 289,839 & 289,839 & 289,839 \\
Year fixed effects & Yes & Yes & Yes \\
\hline \hline
\end{tabular}


Table 5

\section{Investment Model: Robustness Tests}

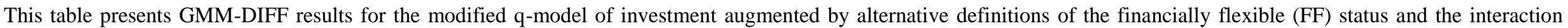
between these dummies and the cash flow proxy. $F F 3(10 \%)(F F 4, F F 5)$ in column $1(2,3)$ is a dummy equal to 1 if a company shows a negative deviation between its target and

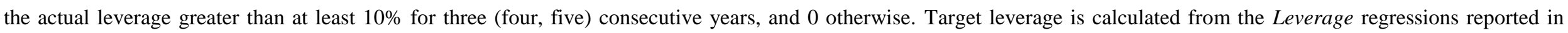

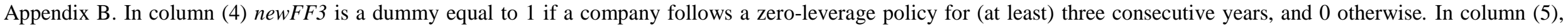
newFF3 is a dummy equal to 1 if a company follows an LL policy for at least three years, including companies that are always below the predicted leverage. Predicted MTBV is

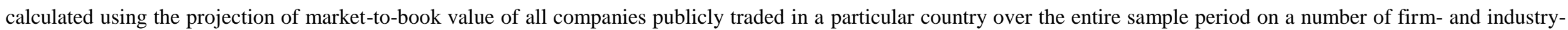
level characteristics that capture the firm's growth opportunities. Please refer to Appendix A for definitions of all other variables. We use suitable lags of all independent

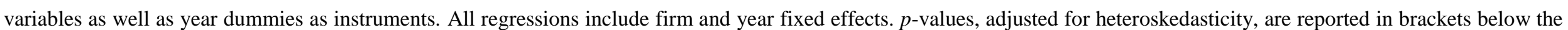
coefficients. *, ** and $* * *$ indicate statistical significance levels of $10 \%, 5 \%$ and $1 \%$, respectively. 


\begin{tabular}{|c|c|c|c|c|c|c|}
\hline & $\begin{array}{c}F F 3 \\
(10 \%)\end{array}$ & $\begin{array}{c}F F 4 \\
(10 \%)\end{array}$ & $\begin{array}{l}F F 5 \\
(10 \%)\end{array}$ & $\begin{array}{c}\text { FF3 } \\
\text { (zero-leverage) }\end{array}$ & $\begin{array}{c}F F 3 \\
\text { (always flexible) }\end{array}$ & $\begin{array}{c}F F 3 \\
\text { Predicted MTBV }\end{array}$ \\
\hline$\frac{\Delta \text { Gross } P P E_{i, t-1}}{K_{i, t-1}}$ & $\begin{array}{c}0.020 * * * \\
{[0.000]}\end{array}$ & $\begin{array}{c}0.020 * * * \\
{[0.000]}\end{array}$ & $\begin{array}{c}0.020 * * * \\
{[0.000]}\end{array}$ & $\begin{array}{c}0.019 * * * \\
{[0.000]}\end{array}$ & $\begin{array}{c}0.020 * * * \\
{[0.000]}\end{array}$ & $\begin{array}{c}0.031 * * * \\
{[0.000]}\end{array}$ \\
\hline$\frac{\operatorname{Cash~Flow~}_{i, t-1}}{K_{i, t-1}}$ & $\begin{array}{c}0.453 * * * \\
{[0.000]}\end{array}$ & $\begin{array}{c}0.435 * * * \\
{[0.000]}\end{array}$ & $\begin{array}{c}0.452 * * * \\
{[0.000]}\end{array}$ & $\begin{array}{c}0.474 * * * \\
{[0.000]}\end{array}$ & $\begin{array}{c}0.473 * * * \\
{[0.000]}\end{array}$ & $\begin{array}{c}0.418 * * * \\
{[0.000]}\end{array}$ \\
\hline Sales growth & $\begin{array}{c}0.216 * * * \\
{[0.000]}\end{array}$ & $\begin{array}{c}0.216 * * * \\
{[0.000]}\end{array}$ & $\begin{array}{c}0.218 * * * \\
{[0.000]}\end{array}$ & $\begin{array}{c}0.237 * * * \\
{[0.000]}\end{array}$ & $\begin{array}{c}0.223 * * * \\
{[0.000]}\end{array}$ & \\
\hline FF dummy (10\%) & $\begin{array}{c}0.165^{* * * *} \\
{[0.000]}\end{array}$ & $\begin{array}{c}0.149 * * * \\
{[0.000]}\end{array}$ & $\begin{array}{c}0.122 * * * \\
{[0.000]}\end{array}$ & & & \\
\hline$\frac{\operatorname{Cash}_{\text {Flow }}, t,-1}{K_{i, t-1}} X F F$ dummy $(10 \%)$ & $\begin{array}{c}-0.095^{* * *} \\
{[0.000]}\end{array}$ & $\begin{array}{c}-0.077 * * * \\
{[0.000]}\end{array}$ & $\begin{array}{c}-0.032 * * * \\
{[0.000]}\end{array}$ & & & \\
\hline Predicted MTBV & & & & & & $\begin{array}{l}0.048^{* *} \\
{[0.025]}\end{array}$ \\
\hline FF dummy & & & & & & $\begin{array}{c}0.129 * * * \\
{[0.000]}\end{array}$ \\
\hline$\frac{\text { Cash } F l o w_{i, t-1}}{K_{i, t-1}} X F F$ dummy & & & & & & $\begin{array}{c}-0.082 * * * \\
{[0.000]}\end{array}$ \\
\hline$n e w F F$ & & & & $\begin{array}{c}0.579 * * * \\
{[0.000]}\end{array}$ & $\begin{array}{c}0.107 * * * \\
{[0.000]}\end{array}$ & \\
\hline$\frac{\text { Cash Flow }_{i, t-1}}{K_{i, t-1}} X$ newFF dummy & & & & $\begin{array}{c}-0.418 * * * \\
{[0.000]}\end{array}$ & $\begin{array}{c}-0.065^{* * *} \\
{[0.000]}\end{array}$ & \\
\hline Observations & $1,598,899$ & $1,598,899$ & $1,598,899$ & $1,598,899$ & $1,598,899$ & $1,469,014$ \\
\hline No. of firms & 289,839 & 289,839 & 289,839 & 289,839 & 289,839 & 287,023 \\
\hline Firm fixed effects & Yes & Yes & Yes & Yes & Yes & Yes \\
\hline Year fixed effects & Yes & Yes & Yes & Yes & Yes & Yes \\
\hline
\end{tabular}


Table 6

\section{Strategic Policy or Credit Rationing: Accumulation Period}

This table shows descriptive statistics of several firm characteristics for FF and Not FF firms (Panel A), and investment results on a matched sample of FF and Not FF firms (Panel B) during the accumulation period. We define "accumulation period" as those years of conservative leverage policy that eventually lead a firm to be classified as FF. We use at least three years of consecutive LL policy to define a company as financially flexible. We use a propensity score matching procedure (Rosenbaum and Rubin, 1983) to identify a control sample of Matched Not FF firms that exhibit no observable differences in characteristics relative to the FF firms during the accumulation period. We calculate the probability of a firm being assigned to the FF group as a function of all firm-level characteristics included in the leverage model. More specifically, the propensity score is estimated within a country-industry-year category, as a function of sales growth, the natural log of total assets, asset tangibility, profitability, non-debt tax shield proxy, taxes, and cash holding. To ensure that the firms in the control sample are sufficiently similar to the FF firms, we require that the maximum difference between the propensity score of the FF firm and that of its matching Not FF peer does not exceed $0.1 \%$ in absolute value. Please refer to Appendix A for definitions of all other variables.

Panel A. Descriptive Statistics

\begin{tabular}{lccc}
\hline \hline & $\boldsymbol{F F}$ & Not $\boldsymbol{F F}$ & $\boldsymbol{P}$-value \\
& & & \\
\hline Size & 6.759 & 6.725 & 0.000 \\
Age & 16.118 & 15.516 & 0.000 \\
Profitability & 0.120 & 0.112 & 0.000 \\
Cash & 0.164 & 0.159 & 0.000 \\
Tangible & 0.202 & 0.221 & 0.000 \\
Sales Growth & 0.446 & 0.479 & 0.000 \\
& & & \\
SAFE & $2.479 \%$ & $4.753 \%$ & 0.000 \\
\hline \hline
\end{tabular}

Panel B. Propensity Score Matching

\begin{tabular}{lcccc}
\hline $\begin{array}{l}\Delta \text { Gross PPE } \\
\boldsymbol{K}_{\boldsymbol{i}, \boldsymbol{t}}\end{array}$ & $\begin{array}{c}\text { No. of } \\
\text { observations }\end{array}$ & Mean & $\begin{array}{c}\text { Difference } \\
\text { (FF firms }- \\
\text { Not FF Firms) }\end{array}$ & $\begin{array}{c}\text { p-value } \\
\text { of diff. }\end{array}$ \\
\hline FF firms & 500,272 & 0.424 & & \\
Matched Not FF firms & 0.425 & -0.001 & 0.548 \\
\hline \hline
\end{tabular}




\section{Table 7}

\section{Strategic Policy or Credit Rationing: After the Accumulation Period}

This table reports, in Panel A, GMM-DIFF results for the modified q-model of investment augmented by the financially flexible (FF) status and the interaction between this dummy and the cash flow proxy. In column (1), the newFF3 dummy is a dummy equal to 1 if a company shows a negative deviation between its target and observed leverage greater than at least $5 \%$ for three consecutive years, and 0 otherwise. Target leverage is calculated from the Leverage regression reported in Appendix B augmented by a proxy for capital markets access, that is, a dummy Public equal to 1 if the company is publicly traded, and 0 otherwise. In column (2), the newFF3 dummy is computed from separate leverage models for public and private companies. Panel B shows the changes in investment and abnormal investment before and after the firm acquires FF status, along with the t-tests on the equality of means. The central observation $t$ corresponds to the time firms are classified as FF. FF is a dummy equal to 1 if a company has a negative deviation from its target for three consecutive years, and 0 otherwise. Adjusted Investment is calculated as the difference between the ratio of investment to capital stock of each firm $i$ each year $\left(\frac{\Delta \mathbf{G r o s s}_{\mathbf{P P E}} \mathbf{i , \mathbf { t }} \mathbf{1}}{\mathbf{K}_{\mathrm{i}, \mathrm{t}-\mathbf{1}}}\right)$ and the average investment to capital stock ratio of all firms in the same country $c$, year and 4-digit NACE Rev 1.1 industry code where the company operates. Adjusted Abnormal Investment is defined over a pattern of five years of industry-adjusted investment data. Normal Investment Activity is the average value of industry-adjusted investments $\left(\boldsymbol{A d} \boldsymbol{j} \boldsymbol{I}_{\boldsymbol{i t}}\right)$ over five-year periods, but excluding the

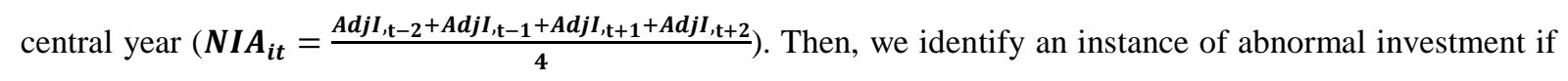

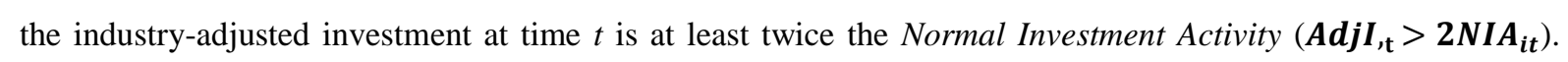
Adjusted Leverage is calculated as the difference between the leverage ratio of each firm $i$ each year and the average leverage ratio of all firms in the same country $c$, year and 4-digit NACE Rev 1.1 industry code where the company operates. Please refer to Appendix A for definitions of all other variables. *,** and *** indicate statistical significance levels of $10 \%, 5 \%$ and $1 \%$, respectively. 
Panel A. Financial Flexibility and Capital Market Access

\begin{tabular}{|c|c|c|}
\hline & $\begin{array}{c}F F 3 \\
\text { Public/Private dummy }\end{array}$ & $\begin{array}{c}\text { FF3 } \\
\text { Public/Private separate models }\end{array}$ \\
\hline$\frac{\Delta \text { Gross } P P E_{i, t-1}}{K_{i, t-1}}$ & $0.020 * * *$ & $0.020 * * *$ \\
\hline & {$[0.000]$} & {$[0.000]$} \\
\hline$\frac{\text { Cash Flow }_{i, t-1}}{K_{i, t-1}}$ & $0.468 * * *$ & $0.470 * * *$ \\
\hline & {$[0.000]$} & {$[0.000]$} \\
\hline Sales growth & $\begin{array}{c}0.223 * * * \\
{[0.000]}\end{array}$ & $\begin{array}{c}0.225 * * * \\
{[0.000]}\end{array}$ \\
\hline$n e w F F$ & $\begin{array}{c}0.136 * * * \\
{[0.000]}\end{array}$ & $\begin{array}{c}0.138 * * * \\
{[0.000]}\end{array}$ \\
\hline$\frac{\text { Cash Flow }_{i, t-1}}{K_{i, t-1}} X$ newFF dummy & $\begin{array}{c}-0.068 * * * \\
{[0.000]}\end{array}$ & $\begin{array}{c}-0.071 * * * \\
{[0.000]}\end{array}$ \\
\hline Observations & $1,598,899$ & $1,598,899$ \\
\hline No. of firms & 289,839 & 289,839 \\
\hline Firm fixed effects & Yes & Yes \\
\hline Year fixed effects & Yes & Yes \\
\hline
\end{tabular}

Panel B. Investment, Abnormal Investment, and Leverage Changes

\begin{tabular}{lccccccc}
\hline \hline & $\boldsymbol{t}-\mathbf{2}$ & $\boldsymbol{t}-\mathbf{1}$ & $\boldsymbol{t}$ & $\boldsymbol{t}+\mathbf{1}$ & $\boldsymbol{t + 2}$ & $\begin{array}{c}\text { Difference in } \\
\text { Means } \boldsymbol{t}-2 \text { vs. } \boldsymbol{t} \\
(\boldsymbol{p} \text {-value })\end{array}$ & $\begin{array}{c}\text { Difference in } \\
\text { Means } \boldsymbol{t} \text { vs. } \boldsymbol{t}+\mathbf{2} \\
(\boldsymbol{p} \text {-value })\end{array}$ \\
\hline $\begin{array}{l}\text { Adjusted Investment } \\
\begin{array}{l}\text { Adjusted Abnormal Investment } \\
\text { \% of FF firms showing }\end{array}\end{array}$ & 0.023 & -0.012 & 0.154 & -0.068 & -0.065 & 0.000 & 0.000 \\
$\begin{array}{l}\text { Adjusted Abnormal Investment } \\
\text { Adjusted Leverage }\end{array}$ & 2.015 & 0.065 & 0.130 & 0.030 & 0.017 & 0.000 & 0.000 \\
\hline \hline
\end{tabular}


Table 8

Investment Model: Leverage and Cash Holding Policy

This table presents GMM-DIFF results for the modified q-model of investment augmented by alternative definitions of the financially flexible (FF) status and the interaction between these dummies and Cash Flow.

NewFF3 in the Net Leverage (column 1) is a dummy equal to 1 if a company shows a negative deviation between its target and the actual leverage greater than at least $5 \%$ for three consecutive years, and 0 otherwise. Target leverage is calculated from Leverage regressions similar to those in Appendix B, where Leverage is defined as net of cash. Similarly, NewFF3 in High Cash holding (column 2) is a dummy equal to 1 if a company shows a negative deviation between its target and the actual leverage greater than at least $5 \%$ for at least three consecutive years, and shows above average industry-adjusted cash levels in the same years, and 0 otherwise. Target leverage is calculated from the Leverage regressions similar to those in Appendix B, where we exclude Cash. Please refer to Appendix A for definitions of all other variables. We use suitable lags of all independent variables, as well as year dummies, as instruments. All regressions include firm and year fixed effects. $p$-values, adjusted for heteroskedasticity, are reported in brackets below the coefficients. $*, * *$ and $* * *$ indicate statistical significance levels of $10 \%, 5 \%$ and $1 \%$, respectively.

\begin{tabular}{|c|c|c|}
\hline & $\begin{array}{c}F F 3 \\
\text { Net Leverage }\end{array}$ & $\begin{array}{c}\text { FF3 } \\
\text { High Cash holding }\end{array}$ \\
\hline$\frac{\Delta \operatorname{Gross} P P E_{i, t-1}}{K_{i, t-1}}$ & $0.020 * * *$ & $0.020 * * *$ \\
\hline & {$[0.000]$} & {$[0.000]$} \\
\hline$\frac{\text { Cash Flow }_{i, t-1}}{K_{i, t-1}}$ & $0.463 * * *$ & $0.467 * * *$ \\
\hline & {$[0.000]$} & {$[0.000]$} \\
\hline Sales growth & $\begin{array}{c}0.225 * * * \\
{[0.000]}\end{array}$ & $\begin{array}{c}0.222 * * * \\
{[0.000]}\end{array}$ \\
\hline$n e w F F$ & $\begin{array}{c}0.084 * * * \\
{[0.000]}\end{array}$ & $\begin{array}{c}0.139 * * * \\
{[0.000]}\end{array}$ \\
\hline$\frac{\text { Cash Flow }_{i, t-1}}{K_{i, t-1}} X$ newFF dummy & $\begin{array}{c}-0.050 * * * \\
{[0.000]} \\
\end{array}$ & $\begin{array}{c}-0.184 * * * \\
{[0.000]} \\
\end{array}$ \\
\hline Observations & $1,598,899$ & $1,598,899$ \\
\hline No. of firms & 289,839 & 289,839 \\
\hline Firm fixed effects & Yes & Yes \\
\hline Year fixed effects & Yes & Yes \\
\hline
\end{tabular}


Table 9

Agency Costs of Equity

This table, in Panel A, presents GMM-DIFF results for the modified q-model of investment augmented by alternative definitions of the financially flexible (FF) status and the interaction between these dummies and Cash Flow. NewFF3 in column (1) (column 2) is the financial flexibility dummy calculated with the target leverage from Leverage regressions similar to those in Appendix B, augmented by the Cash Flow Rights of the ultimate largest shareholder (the ratio of annual sales to total assets as in Ang et al., 2000). We use suitable lags of all independent variables as well as year dummies as instruments. All regressions include firm and year fixed effects. $p$-values, adjusted for heteroskedasticity, are reported in brackets below the coefficients. Panel B reports percentage changes in Profitability of FF firms before and after FF status is acquired (time $t$ ) or after Abnormal Investments have been made. Please refer to Appendix A and the notes to Table 7 for definitions of all variables. $*, * *$ and $* * *$ indicate statistical significance levels of $10 \%, 5 \%$ and $1 \%$, respectively.

Panel A. Investment Model

\begin{tabular}{|c|c|c|c|c|c|}
\hline & \multicolumn{3}{|c|}{$\begin{array}{c}\text { FF3 } \\
\text { Cash Flow Rights }\end{array}$} & \multicolumn{2}{|c|}{$\begin{array}{c}\text { FF3 } \\
\text { Annual Sales to Total Assets }\end{array}$} \\
\hline$\frac{\Delta \text { Gross } P P E_{i, t-1}}{K}$ & \multicolumn{3}{|c|}{$0.044 * * *$} & \multicolumn{2}{|c|}{$0.020 * * *$} \\
\hline & \multicolumn{3}{|c|}{$[0.000]$} & \multicolumn{2}{|c|}{$[0.000]$} \\
\hline$\frac{\text { Cash Flow }_{i, t-1}}{K_{i, t-1}}$ & \multicolumn{3}{|c|}{$0.235^{* * *}$} & \multicolumn{2}{|c|}{$0.469 * * *$} \\
\hline & \multicolumn{3}{|c|}{$[0.000]$} & \multicolumn{2}{|c|}{$[0.000]$} \\
\hline Sales growth & \multicolumn{3}{|c|}{$\begin{array}{c}0.143 * * * \\
{[0.000]}\end{array}$} & \multicolumn{2}{|c|}{$0.226 * * *$} \\
\hline$n e w F F$ & \multicolumn{3}{|c|}{$0.052 * * *$} & \multicolumn{2}{|c|}{$\begin{array}{c}0.138 * * * \\
{[0.000]}\end{array}$} \\
\hline 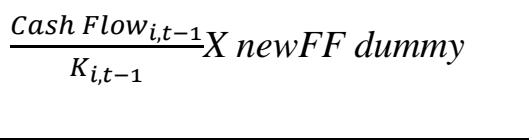 & \multicolumn{3}{|c|}{$-0.016 * * *$} & \multicolumn{2}{|c|}{$-0.072 * * *$} \\
\hline Observations & \multicolumn{3}{|c|}{48,058} & \multicolumn{2}{|c|}{$1,598,899$} \\
\hline No. of firms & \multicolumn{3}{|c|}{14,221} & \multicolumn{2}{|c|}{289,839} \\
\hline Firm fixed effects & \multicolumn{3}{|c|}{ Yes } & \multicolumn{2}{|c|}{ Yes } \\
\hline Year fixed effects & \multicolumn{3}{|c|}{ Yes } & \multicolumn{2}{|c|}{ Yes } \\
\hline \multicolumn{6}{|c|}{ Panel B. Performance Analysis } \\
\hline & No. of firms & Pre & Post & $\begin{array}{l}\% \text { Diff. } \\
\text { Post-Pre }\end{array}$ & $\begin{array}{l}p \text {-val of Diff. } \\
\text { Post-Pre }\end{array}$ \\
\hline Profitability $(t-1$ to $t+1)$ & 191,917 & 0.111 & 0.117 & $5.392 \%$ & 0.000 \\
\hline $\begin{array}{l}\text { Profitability }(t-1 \text { to } t+2) \\
\text { Profitability with }\end{array}$ & 135,969 & 0.110 & 0.118 & $6.455 \%$ & 0.000 \\
\hline $\begin{array}{l}\text { abnormal investment ( } t-1 \text { to } t+1 \text { ) } \\
\text { Profitability with }\end{array}$ & 50,470 & 0.118 & 0.128 & $7.693 \%$ & 0.000 \\
\hline abnormal investment ( $t-1$ to $t+2)$ & 54 & 0.122 & 0.153 & $20.674 \%$ & 0.005 \\
\hline
\end{tabular}


Table 10

Investment Models: Private versus Public Firms

This table presents GMM-DIFF results for the modified q-model of investment augmented by alternative definitions of financially flexible (FF) status and the interaction between these dummies and the cash flow proxy. The two subsamples are identified on the basis of the listing status of each firm in the year when the firm is identified as Financially Flexible. Please refer to Appendix A for definitions of all variables. We use suitable lags of all independent variables as well as year dummies as instruments. All regressions include firm and year fixed effects. Diff. FF dummy ( $p$-val) is the p-value of the difference between the coefficients of $F F$ dummy across subsamples: (Public-Private). $p$-values, adjusted for heteroskedasticity, are reported in brackets below the coefficients. *,* and *** indicate statistical significance levels of $10 \%, 5 \%$ and $1 \%$, respectively.

\begin{tabular}{|c|c|c|c|c|}
\hline \multirow{4}{*}{$\frac{\Delta \operatorname{Gross} P P E_{i, t-1}}{K_{i, t-1}}$} & Private & Public & Private & Public \\
\hline & \multicolumn{2}{|c|}{ FF3 } & \multicolumn{2}{|c|}{ FF5 } \\
\hline & $0.020 * * *$ & $0.045^{* * *}$ & $0.020 * * *$ & $0.047 * * *$ \\
\hline & {$[0.000]$} & {$[0.000]$} & {$[0.000]$} & {$[0.000]$} \\
\hline$\frac{\text { Cash Flow }_{i, t-1}}{K_{i, t-1}}$ & $0.470 * * *$ & $0.072 * * *$ & $0.460 * * *$ & $0.098 * * *$ \\
\hline & {$[0.000]$} & {$[0.000]$} & {$[0.000]$} & {$[0.000]$} \\
\hline Sales growth & $\begin{array}{c}0.222 * * * \\
{[0.000]}\end{array}$ & $\begin{array}{c}0.167 * * * \\
{[0.000]}\end{array}$ & $\begin{array}{c}0.216^{* * * *} \\
{[0.000]}\end{array}$ & $\begin{array}{c}0.145^{* * *} * \\
{[0.000]}\end{array}$ \\
\hline FF dummy & $\begin{array}{c}0.139 * * * \\
{[0.000]}\end{array}$ & $\begin{array}{c}0.037 * * * \\
{[0.000]}\end{array}$ & $\begin{array}{c}0.130 * * * \\
{[0.000]}\end{array}$ & $\begin{array}{c}0.095 * * * \\
{[0.000]}\end{array}$ \\
\hline$\frac{\text { Cash Flow }_{i, t-1}}{K_{i, t-1}} X F F$ dummy & $\begin{array}{c}-0.073 * * * \\
{[0.000]} \\
\end{array}$ & $\begin{array}{c}-0.010^{* * *} \\
{[0.000]} \\
\end{array}$ & $\begin{array}{c}-0.051 * * * \\
{[0.000]} \\
\end{array}$ & $\begin{array}{c}-0.066^{* * * *} \\
{[0.000]} \\
\end{array}$ \\
\hline Diff. FF dummy ( $p$-val) & 0.000 & & 0.000 & \\
\hline Observations & $1,595,630$ & 3,901 & $1,595,630$ & 3,901 \\
\hline No. of firms & 289,504 & 565 & 289,504 & 565 \\
\hline Firm fixed effects & Yes & Yes & Yes & Yes \\
\hline Year fixed effects & Yes & Yes & Yes & Yes \\
\hline
\end{tabular}




\section{Table 11}

\section{Investment Models: Firms Size and Age}

This table presents GMM-DIFF results for the modified q-model of investment augmented by the financially flexible (FF) status dummy FF3 and the interaction between this dummy and the cash flow proxy. Small, Medium, and Large firms are identified using the tertile distribution of the (logarithm of) total assets in each country each year. Young and Mature firms are identified in the bottom and top tertile of Age distribution. We use suitable lags of all independent variables as well as year dummies as instruments. All regressions include firm and year fixed effects. Diff. FF dummy ( $p$-val) is the $p$-value of the difference between the coefficients of $F F$ dummy across subsamples: (Large-Small); (Mature-Young); and (Large \& Mature-Small \& Young). p-values, adjusted for heteroskedasticity, are reported in brackets below the coefficients. $* * *$ and $* * *$ indicate statistical significance levels of $10 \%, 5 \%$ and $1 \%$, respectively.

\begin{tabular}{|c|c|c|c|c|c|c|c|}
\hline \multirow[b]{3}{*}{$\triangle$ Gross $P P E_{i, t-1}$} & Small & Medium & Large & Young & Mature & Small \& Young & Large \& Mature \\
\hline & \multicolumn{3}{|c|}{ FF3 } & \multicolumn{2}{|c|}{ FF3 } & \multicolumn{2}{|c|}{ FF3 } \\
\hline & $0.008 * * *$ & $0.019 * * *$ & $0.034 * * *$ & $0.020 * * *$ & $0.007 * * *$ & $0.006^{* * *}$ & $0.013 * * *$ \\
\hline$K_{i, t-1}$ & {$[0.000]$} & {$[0.000]$} & {$[0.000]$} & {$[0.000]$} & {$[0.000]$} & {$[0.000]$} & {$[0.000]$} \\
\hline \multirow{2}{*}{$K_{i, t-1}$} & $0.463 * * *$ & $0.374 * * *$ & $0.371 * * *$ & $0.437 * * *$ & $0.408 * * *$ & $0.372 * * *$ & $0.344 * * *$ \\
\hline & {$[0.000]$} & {$[0.000]$} & {$[0.000]$} & {$[0.000]$} & {$[0.000]$} & {$[0.000]$} & {$[0.000]$} \\
\hline \multirow[t]{2}{*}{ Sales growth } & $0.220 * * *$ & $0.075^{* * *}$ & $0.079 * * *$ & $0.180 * * *$ & $0.064 * * *$ & $0.347 * * *$ & $0.051 * * *$ \\
\hline & {$[0.000]$} & {$[0.000]$} & {$[0.000]$} & {$[0.000]$} & {$[0.000]$} & {$[0.000]$} & {$[0.000]$} \\
\hline \multirow[t]{2}{*}{$F F$ dummy } & $0.145^{* * *}$ & $0.098 * * *$ & $0.090 * * *$ & $0.159 * * *$ & $0.101 * * *$ & $0.154 * * *$ & $0.101 * * *$ \\
\hline & {$[0.000]$} & {$[0.000]$} & {$[0.000]$} & {$[0.000]$} & {$[0.000]$} & {$[0.000]$} & {$[0.000]$} \\
\hline \multirow[t]{2}{*}{$\frac{\text { Cash } \text { low }_{i, t-1}}{K_{i, t-1}} X F F$ dummy } & $-0.129 * * *$ & $-0.051 * * *$ & $-0.039 * * *$ & $-0.084 * * *$ & $-0.105 * * *$ & $-0.119 * * *$ & $-0.120 * * *$ \\
\hline & {$[0.000]$} & {$[0.000]$} & {$[0.000]$} & {$[0.000]$} & {$[0.000]$} & [0.000] & {$[0.000]$} \\
\hline Diff. FF dummy ( $p$-val) & 0.000 & & & 0.000 & & 0.000 & \\
\hline Observations & 565,447 & 397,362 & 315,461 & $1,033,110$ & 56,496 & 441,426 & 16,684 \\
\hline No. of firms & 143,153 & 107,398 & 65,614 & 233,361 & 14,121 & 135,159 & 4,666 \\
\hline Firm fixed effects & Yes & Yes & Yes & Yes & Yes & Yes & Yes \\
\hline Year fixed effects & Yes & Yes & Yes & Yes & Yes & Yes & Yes \\
\hline
\end{tabular}


Table 12

Investment Models: Credit Accessibility and Investor Protection

This table presents GMM-DIFF results for the modified q-model of investment augmented by the financially flexible (FF) status dummies (FF3 and FF5) and the interaction between these dummies and the cash flow proxy. Low/High Credit Access Index (Anti-Self-Dealing Index) is an indicator equal to 1 if the country where the firm operates has a below/above-median value of the Credit Access Index (Anti-Self-Dealing Index). Please refer to Appendix A for definitions of all variables. We use suitable lags of all independent variables as well as year dummies as instruments. All regressions include firm and year fixed effects. Diff. FF dummy ( $p$-val) is the $p$-value of the difference between the coefficients of FF dummy across subsamples within each index. $p$-values, adjusted for heteroskedasticity, are reported in brackets below the coefficients. *,** and $* * *$ indicate statistical significance levels of $10 \%, 5 \%$ and $1 \%$, respectively.

\begin{tabular}{|c|c|c|c|c|c|c|c|c|}
\hline & \multicolumn{4}{|c|}{ Credit Access Index } & \multicolumn{4}{|c|}{ Anti-Self-Dealing Index } \\
\hline & Low & High & Low & High & Low & High & Low & High \\
\hline & \multicolumn{2}{|c|}{ FF3 } & \multicolumn{2}{|c|}{ FF5 } & \multicolumn{2}{|c|}{ FF3 } & \multicolumn{2}{|c|}{ FF5 } \\
\hline \multirow[t]{2}{*}{$K_{i, t-1}$} & $0.020 * * *$ & $0.040 * * *$ & $0.020 * * *$ & $0.038 * * *$ & $0.021 * * *$ & $0.028 * * *$ & $0.021 * * *$ & $0.030 * * *$ \\
\hline & {$[0.000]$} & {$[0.000]$} & {$[0.000]$} & {$[0.000]$} & {$[0.000]$} & {$[0.000]$} & {$[0.000]$} & {$[0.000]$} \\
\hline \multirow{2}{*}{$K_{i, t-1}$} & $0.475 * * *$ & $0.284^{* * *}$ & $0.463 * * *$ & $0.282 * * *$ & $0.470 * * *$ & $0.380 * * *$ & $0.459 * * *$ & $0.389 * * *$ \\
\hline & {$[0.000]$} & {$[0.000]$} & {$[0.000]$} & {$[0.000]$} & {$[0.000]$} & {$[0.000]$} & {$[0.000]$} & {$[0.000]$} \\
\hline \multirow[t]{2}{*}{ Sales growth } & $0.221 * * *$ & $0.042 * * *$ & $0.215^{* * *}$ & $0.039 * * *$ & $0.201^{* * *}$ & $0.029 * *$ & $0.196^{* * *}$ & $0.025^{* *}$ \\
\hline & {$[0.000]$} & {$[0.000]$} & {$[0.000]$} & {$[0.000]$} & {$[0.000]$} & {$[0.010]$} & {$[0.000]$} & [0.016] \\
\hline \multirow[t]{2}{*}{ FF dummy } & $0.141 * * *$ & $0.042 * * *$ & $0.132 * * *$ & $0.052 * * *$ & $0.138 * * *$ & $0.048 * * *$ & $0.133 * * *$ & $0.037 * * *$ \\
\hline & {$[0.000]$} & {$[0.000]$} & {$[0.000]$} & {$[0.000]$} & {$[0.000]$} & {$[0.000]$} & {$[0.000]$} & {$[0.000]$} \\
\hline \multirow[t]{2}{*}{$\frac{\text { Cash } \text { Flow }_{i, t-1}}{K_{i, t-1}} X F F$ dummy } & $-0.075 * * *$ & $-0.014 * * *$ & $-0.053 * * *$ & $-0.022 * * *$ & $-0.071 * * *$ & $-0.013 * * *$ & $-0.054 * * *$ & $-0.009 * * *$ \\
\hline & {$[0.000]$} & {$[0.000]$} & {$[0.000]$} & {$[0.000]$} & {$[0.000]$} & {$[0.000]$} & {$[0.000]$} & {$[0.000]$} \\
\hline Diff. FF dummy ( $p$-val) & 0.000 & & 0.000 & & 0.000 & & 0.000 & \\
\hline Observations & $1,539,311$ & 59,588 & $1,539,311$ & 59,588 & $1,498,931$ & 99,968 & $1,498,931$ & 99,968 \\
\hline No. of firms & 278,122 & 11,717 & 278,122 & 11,717 & 268,563 & 21,276 & 268,563 & 21,276 \\
\hline Firm fixed effects & Yes & Yes & Yes & Yes & Yes & Yes & Yes & Yes \\
\hline Year fixed effects & Yes & Yes & Yes & Yes & Yes & Yes & Yes & Yes \\
\hline
\end{tabular}


Table 13

\section{Liquidity Shock and Financial Flexibility}

This table reports results on the investment, leverage, and cash holding levels and investment sensitivity to cash flow for a subsample of firms during the financial crisis. In particular, we focus on companies in 2006, the year before the emergence of the financial crisis, and distinguish those that are financially flexible (FF) from those that are not (Not FF) and a matched subsample of those that are not (Matched Not FF). To classify a firm as financially flexible FF3 (FF5), we require it to have a low-leverage (LL) policy for at least three (five) consecutive years. Panel A shows the average levels of capital expenditure of firm $i$ relative to capital stock over the period 2003-2006 (Pre-crisis) and over the period 2007-2010 (During crisis) for the three groups of firms. Panel B shows the average levels of leverage and cash holding of firm $i$ over the period 2003-2006 (Pre-crisis) and over the period 2007-2010 (During crisis) for the three groups of firms. Panel C reports the GMM-DIFF results of a simple q-model of investment estimated for the years affected by the financial crisis (2007-2010) only on the three groups of firms, FF versus Not FF and FF versus Matched Not FF. Diff. ( $p$-val) is the $p$-value of the difference between the coefficients of $\frac{\text { Cash Flow }_{i, t-1}}{K_{i, t-1}}$ across subsamples: (Not FF - FF) and (Matched Not FF - FF). Please refer to Appendix A for definitions of all variables. We use suitable lags of all independent variables as well as year dummies as instruments. All regressions include firm and year fixed effects. $p$-values, adjusted for heteroskedasticity, are reported in brackets below the coefficients. *, ** and *** indicate statistical significance levels of $10 \%, 5 \%$ and $1 \%$, respectively.

Panel A. Average Investment Levels before and during the Crisis

\begin{tabular}{lcccccc}
\hline \hline & $\begin{array}{c}\text { No. of } \\
\text { firms }\end{array}$ & $\begin{array}{c}\text { Pre- } \\
\text { crisis }\end{array}$ & $\begin{array}{c}\text { During } \\
\text { crisis }\end{array}$ & $\begin{array}{c}\Delta \text { Mean } \\
\text { During-Pre }\end{array}$ & $\begin{array}{c}\text { p-val of diff. } \\
\text { During-Pre }\end{array}$ & $\begin{array}{c}\text { p-val of diff. } \\
\text { FF-NotFF, } \\
\text { FF-Matched NotFF }\end{array}$ \\
\hline All sample & 219,953 & 0.384 & 0.254 & -0.130 & 0.000 & \\
\hline FF firms & 39,226 & 0.336 & 0.268 & -0.068 & 0.000 & \\
Not FF firms & 180,727 & 0.394 & 0.250 & -0.144 & 0.000 & 0.000 \\
$\begin{array}{l}\text { Matched Not } \\
\text { FF firms }\end{array}$ & 39,226 & 0.393 & 0.255 & -0.138 & 0.000 & 0.000 \\
\hline & & & & $\boldsymbol{F F 5}$ & & \\
\hline FF firms & 14,918 & 0.254 & 0.242 & -0.012 & 0.008 & 0.000 \\
Not FF firms & 205,035 & 0.393 & 0.254 & -0.139 & 0.000 & 0.000 \\
$\begin{array}{l}\text { Matched Not } \\
\text { FF firms }\end{array}$ & 14,918 & 0.394 & 0.244 & -0.150 & 0.000 & \\
\hline \hline
\end{tabular}


Table 13

(Continued)

Panel B. Average Leverage and Cash Holding Levels before and during the Crisis

\begin{tabular}{|c|c|c|c|c|c|c|}
\hline & $\begin{array}{l}\text { No. of } \\
\text { firms }\end{array}$ & $\begin{array}{l}\text { Pre- } \\
\text { crisis }\end{array}$ & $\begin{array}{c}\text { During } \\
\text { crisis }\end{array}$ & $\begin{array}{c}\Delta \text { Mean } \\
\text { During-Pre }\end{array}$ & $\begin{array}{l}p \text {-val of diff. } \\
\text { During-Pre }\end{array}$ & $\begin{array}{c}p \text {-val of diff. } \\
\text { FF-NotFF, } \\
\text { FF-Matched NotFF }\end{array}$ \\
\hline & \multicolumn{6}{|c|}{ Leverage } \\
\hline All sample & 219,953 & 0.144 & 0.167 & 0.023 & 0.000 & \\
\hline FF firms & 39,226 & 0.048 & 0.132 & 0.084 & 0.000 & \\
\hline $\begin{array}{l}\text { Not FF firms } \\
\text { Matched Not }\end{array}$ & 180,727 & 0.167 & 0.175 & 0.008 & 0.000 & 0.000 \\
\hline \multirow[t]{2}{*}{ FF firms } & 39,226 & 0.159 & 0.171 & 0.012 & 0.000 & 0.000 \\
\hline & \multicolumn{6}{|c|}{ Cash Holding } \\
\hline All sample & 0.167 & 0.164 & -0.003 & 0.000 & 0.167 & \\
\hline FF firms & 0.176 & 0.173 & -0.003 & 0.000 & 0.176 & \\
\hline $\begin{array}{l}\text { Not FF firms } \\
\text { Matched Not }\end{array}$ & 0.165 & 0.162 & -0.003 & 0.000 & 0.165 & 0.930 \\
\hline FF firms & 0.164 & 0.161 & -0.004 & 0.000 & 0.164 & 0.795 \\
\hline
\end{tabular}

Panel C. Investment Regressions

\begin{tabular}{|c|c|c|c|c|c|c|}
\hline & \multicolumn{3}{|c|}{$F F 3$} & \multicolumn{3}{|c|}{ FF5 } \\
\hline & $\mathbf{F F}$ & Not FF & $\begin{array}{l}\text { Matched } \\
\text { Not FF }\end{array}$ & FF & Not FF & $\begin{array}{c}\text { Matched } \\
\text { Not FF }\end{array}$ \\
\hline$\frac{\Delta \operatorname{Gross} P P E_{i, t-1}}{K_{i, t-1}}$ & $0.020 * *$ & $0.008^{*}$ & 0.002 & $0.024^{*}$ & $0.010 * *$ & -0.008 \\
\hline & [0.011] & {$[0.096]$} & {$[0.803]$} & {$[0.100]$} & {$[0.016]$} & {$[0.587]$} \\
\hline$\frac{\text { Cash Flow }_{i, t-1}}{K_{i, t-1}}$ & $0.305 * * *$ & $0.371 * * *$ & $0.407 * * *$ & $0.177 * * *$ & $0.380 * * *$ & $0.239 * * *$ \\
\hline & {$[0.000]$} & {$[0.000]$} & {$[0.000]$} & {$[0.000]$} & {$[0.000]$} & {$[0.000]$} \\
\hline Sales growth & $\begin{array}{c}0.397 * * * \\
{[0.000]}\end{array}$ & $\begin{array}{c}0.341 * * * \\
{[0.000]}\end{array}$ & $\begin{array}{c}0.360 * * * \\
{[0.000]}\end{array}$ & $\begin{array}{c}0.428 * * * \\
{[0.000]}\end{array}$ & $\begin{array}{c}0.347 * * * \\
{[0.000]}\end{array}$ & $\begin{array}{c}0.390 * * * \\
{[0.000]}\end{array}$ \\
\hline Diff. $\frac{\text { Cash Flow }_{i, t-1}}{K_{i, t-1}}(p$-val $)$ & & 0.000 & 0.000 & & 0.000 & 0.000 \\
\hline Observations & 45,328 & 186,190 & 45,328 & 18,165 & 213,353 & 18,165 \\
\hline No. of firms & 28,214 & 125,319 & 28,214 & 10,836 & 142,697 & 10,836 \\
\hline Firm fixed effects & Yes & Yes & Yes & Yes & Yes & Yes \\
\hline Year fixed effects & Yes & Yes & Yes & Yes & Yes & Yes \\
\hline
\end{tabular}


Figure 1

Investment Models and Institutional Setting

This figure shows the plot of each country's estimated financially flexible status dummy (FF3) with respect to each country's Credit Access Index (Panel A) and Anti-Self-Dealing Index (Panel B). Please refer to Appendix A for definitions of variables.

Panel A. Credit Access Index

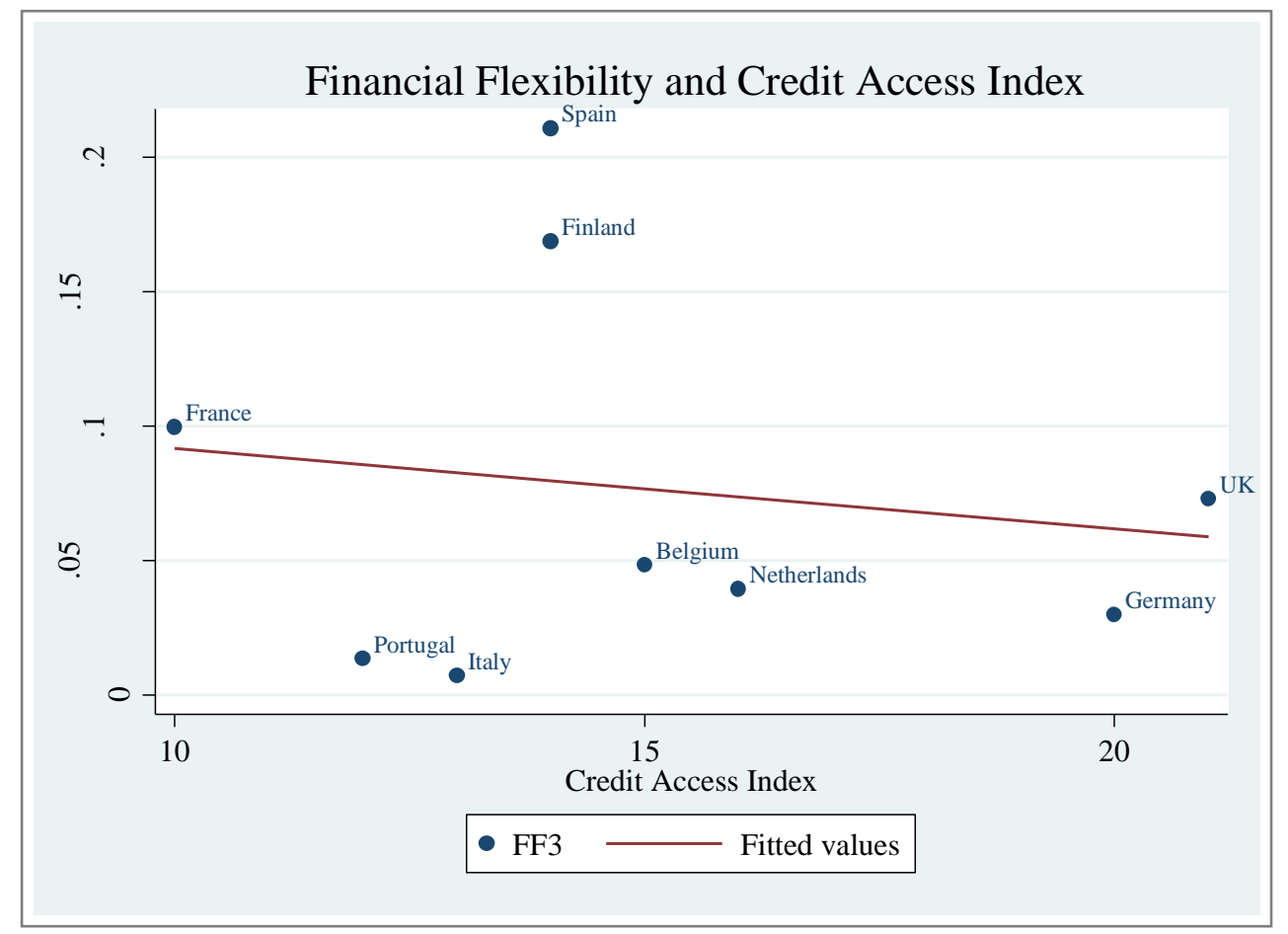

Panel B. Investor Protection Index

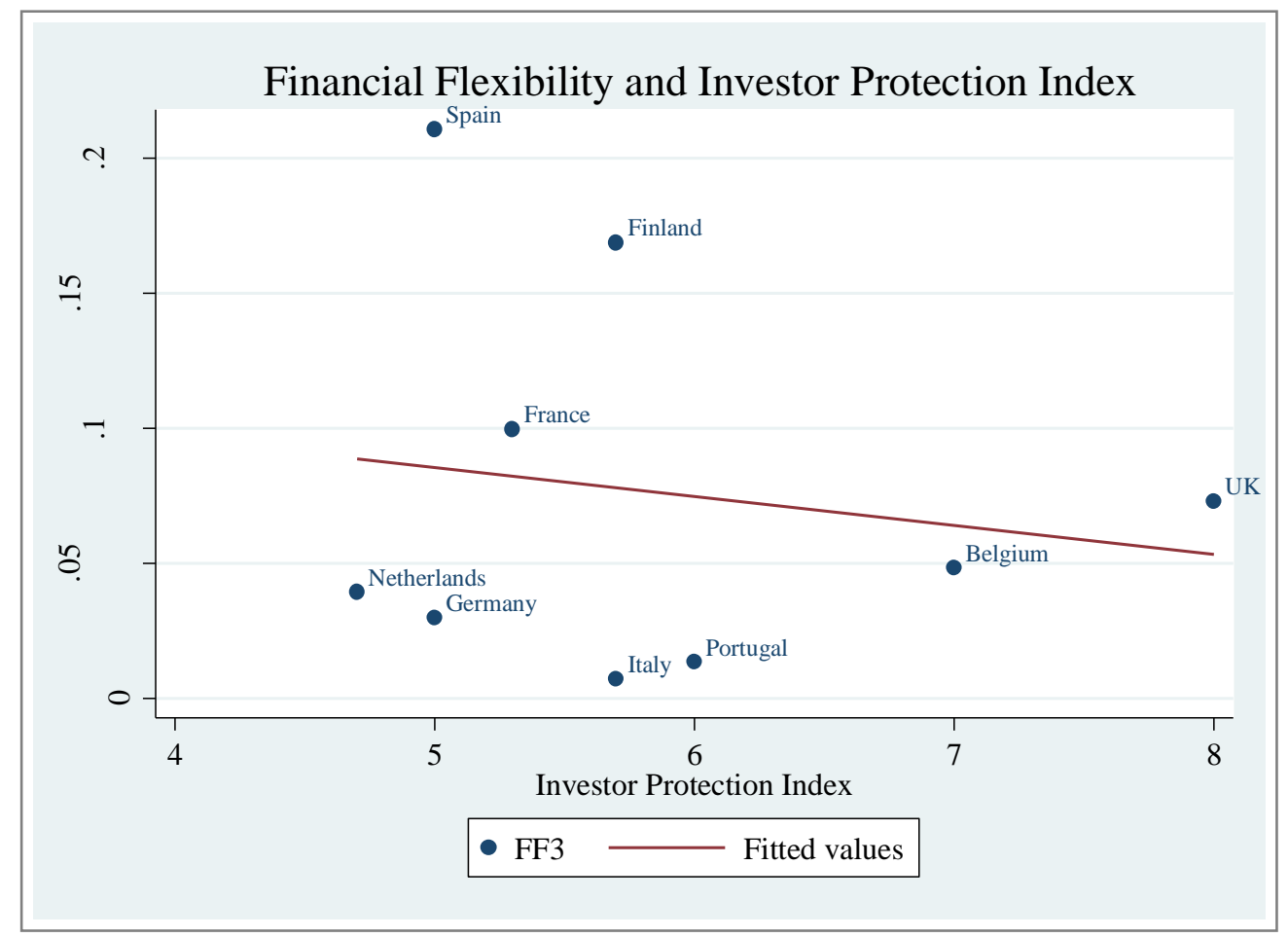




\section{Appendix A \\ Variable Definitions}

\begin{tabular}{|c|c|}
\hline Variable & Definition \\
\hline$\frac{\Delta \text { Gross } P P E_{i, t}}{K_{i, t-1}}$ & $\begin{array}{l}\text { Ratio of capital expenditure to the beginning-of-year capital stock. Capital expenditure is } \\
\text { computed as annual change in (net) total fixed assets plus depreciation. }\end{array}$ \\
\hline$K_{i, t}$ & $\begin{array}{l}\text { Capital stock is constructed using the perpetual inventory method. Since the values available for } \\
\text { capital stock are at book value (that is, at historical prices), we multiply the value at historical } \\
\text { prices for the first year of observation available for each firm by a factor adjusting for historical } \\
\text { inflation to get an estimation of the initial value }\left(K_{i, t}\right) \text { of capital stock at replacement value (that } \\
\text { is, at time } t_{1} \text { prices). The perpetual inventory formula is then used to obtain the estimated value of } \\
\text { the stock of capital at replacement cost in the subsequent times: } K_{i, t}=(1-\delta) K_{i, t-1}+ \\
\frac{\Delta \text { Gross PPE } i, t}{G D P \text { deflator }} \text {, where } \delta \text { is the depreciation rate of the stock of capital (based on aggregate data at } \\
\text { country level). }\end{array}$ \\
\hline$\frac{\text { Cash Flow }_{i, t-1}}{K_{i, t-1}}$ & Ratio of cash flow to capital stock, where cash flow is net income plus depreciation. \\
\hline Sales Growth & Annual growth rate of sales. \\
\hline $\begin{array}{l}\text { FF dummies } \\
(F F 3, F F 4 \text {, and FF5) }\end{array}$ & $\begin{array}{l}\text { Financially flexible status dummy equal to } 1 \text { when we observe at least three (four or five) } \\
\text { consecutive periods in which the firm is classified as } L L \text {, where } L L \text { is an indicator equal to } 1 \text { if the } \\
\text { firm in each country each year exhibits a negative deviation between its actual and predicted } \\
\text { leverage. We require the deviation to be greater than } 5 \% \text {. }\end{array}$ \\
\hline Leverage & Ratio of total debt (loans and long-term debt) to total assets. \\
\hline Private (Public) & Dummy equal to 1 if the company is privately held (publicly traded), zero otherwise. \\
\hline Sales Growth & Annual growth rate of sales. \\
\hline Size & Natural log of total assets (in $€$ mil), expressed in real value. \\
\hline Tangibility & Ratio of tangible fixed assets to total assets. \\
\hline Profitability & Ratio of earnings before interest, taxes and depreciation to total assets. \\
\hline Ndts & Ratio of depreciation to total assets. \\
\hline $\operatorname{Tax}$ & Ratio of total tax charge to total assets. \\
\hline Cash & Ratio of cash and cash equivalents to total assets. \\
\hline Age & Number of years since incorporation. \\
\hline SAFE & $\begin{array}{l}\text { The SAFE score is defined on the basis of the following estimated coefficients: } S A F E_{\text {score }}= \\
-1.88+0.71 \text { finlev }+0.28 \text { ifp }-0.51 \text { profitmargin }-0.21 \text { collateral }-1.2 \text { cashholding }- \\
0.05 \ln T A \text {, where finlev stands for the ratio of financial debt over total assets; ifp stands for } \\
\text { index of financial pressure and is computed as a ratio between interest payments and the sum of } \\
\text { profits, depreciation, and interest payments itself; profitmargin is the ratio of operating profits } \\
\text { over turnover; collateral is the ratio of fixed assets over total assets; cashholding is the ratio of } \\
\text { cash and cash equivalents over total assets; } \ln T A \text { is the natural logarithm of total assets. }\end{array}$ \\
\hline
\end{tabular}




\section{Appendix A}

\section{(Continued)}

\begin{tabular}{|l|l|}
\hline \multirow{1}{*}{ Credit Access Index } & $\begin{array}{l}\text { An index that measures the legal rights of borrowers and lenders with respect to secured } \\
\text { transactions and the sharing of credit information as provided by World Bank-Doing Business } \\
\text { Project. It sums up four indices: 1) the strength of legal rights index; 2) the depth of credit } \\
\text { information index; 3) the public credit registry index; and 4) the private credit bureau index (the } \\
\text { latter two indexes measure the coverage of public credit registry and private credit bureaus, } \\
\text { respectively, in each country). These two indices range from 1 to 5, respectively, with higher } \\
\text { values indicating higher number of individuals and firms listed in a public credit registry (or } \\
\text { private credit bureau), with information on their borrowing history from the preceding 5 years. } \\
\text { For each country, we add up the four scores to obtain a final composite index of credit } \\
\text { accessibility. The resulting index ranges from 0 to 26, with higher values indicating higher credit }\end{array}$ \\
\hline Anti-Self-Dealing Index & $\begin{array}{l}\text { An index that measures the strength of minority shareholder protection against directors' misuse } \\
\text { of corporate assets for personal gain. It includes three main components: 1) extent of disclosure } \\
\text { index; 2) extent of director liability index; and 3) ease of shareholder suits index (Djankov et al., } \\
\text { 2008). This composite index ranges from 0 to 10, with higher values indicating more investor } \\
\text { protection. }\end{array}$ \\
\hline
\end{tabular}




\section{Appendix B}

\section{Leverage Model: Baseline Regressions}

This table reports the GMM-SYS estimations for the leverage model at country level. We use suitable lags of all independent variables as well as year dummies as instruments. All regressions include firm and year fixed effects. $p$-values, adjusted for heteroskedasticity, are reported in brackets below the coefficients. Please refer to Appendix A for definitions of all variables. *,** and *** indicate statistical significance levels of $10 \%, 5 \%$ and $1 \%$, respectively.

\begin{tabular}{|c|c|c|c|c|c|c|c|c|c|}
\hline & Belgium & Finland & France & Germany & Italy & Netherlands & Portugal & Spain & $\boldsymbol{U K}$ \\
\hline \multirow[t]{2}{*}{$L e v_{i, t-1}$} & $0.728 * * *$ & $0.672 * * *$ & $0.472 * * *$ & $0.380 * * *$ & $0.641 * * *$ & $0.563 * * *$ & $0.528 * * *$ & $0.674 * * *$ & $0.580 * * *$ \\
\hline & {$[0.000]$} & {$[0.000]$} & {$[0.000]$} & {$[0.000]$} & {$[0.000]$} & {$[0.000]$} & {$[0.000]$} & {$[0.000]$} & {$[0.000]$} \\
\hline \multirow[t]{2}{*}{ Sales growth } & $0.022 * * *$ & $0.015 * * *$ & $0.007 * * *$ & $0.011 * * *$ & $0.001 * * *$ & $0.000 * *$ & $0.005 * * *$ & $0.011 * * *$ & $0.005 * * *$ \\
\hline & {$[0.000]$} & {$[0.000]$} & {$[0.000]$} & [0.000] & {$[0.000]$} & {$[0.015]$} & {$[0.000]$} & {$[0.000]$} & {$[0.000]$} \\
\hline \multirow[t]{2}{*}{ Size } & $0.012 * * *$ & 0.0004 & 0.00007 & $-0.016 * * *$ & $0.015 * * *$ & $0.008 * * *$ & $0.010 * * *$ & $0.007 * * *$ & $0.006 * * *$ \\
\hline & {$[0.000]$} & {$[0.419]$} & {$[0.722]$} & {$[0.000]$} & {$[0.000]$} & {$[0.000]$} & {$[0.000]$} & {$[0.000]$} & {$[0.000]$} \\
\hline \multirow[t]{2}{*}{ Tangibility } & $0.136 * * *$ & $0.128 * * *$ & $0.153 * * *$ & $0.146 * * *$ & $0.057 * * *$ & $0.065 * * *$ & $0.085 * * *$ & $0.116 * * *$ & $0.062 * * *$ \\
\hline & {$[0.000]$} & {$[0.000]$} & {$[0.000]$} & [0.000] & {$[0.000]$} & [0.000] & {$[0.000]$} & {$[0.000]$} & {$[0.000]$} \\
\hline \multirow[t]{2}{*}{ Profitability } & $-0.075 * * *$ & -0.011 & $0.033 * * *$ & $-0.068 * * *$ & $0.035 * * *$ & $-0.042 * * *$ & $0.075 * * *$ & $0.161 * * *$ & $-0.038 * * *$ \\
\hline & {$[0.000]$} & [0.156] & {$[0.000]$} & [0.000] & {$[0.000]$} & [0.000] & {$[0.000]$} & [0.000] & [0.000] \\
\hline \multirow[t]{2}{*}{$N d t s$} & $-0.187 * * *$ & $-0.229 * * *$ & $-0.184 * * *$ & $0.166^{* * *}$ & $-0.186^{* * *}$ & $-0.081 * * *$ & $-0.309 * * *$ & $-0.518 * * *$ & $-0.124 * *$ \\
\hline & {$[0.000]$} & {$[0.000]$} & [0.000] & [0.003] & {$[0.000]$} & {$[0.000]$} & [0.000] & {$[0.000]$} & [0.043] \\
\hline \multirow[t]{2}{*}{$\operatorname{Tax}$} & $-0.009 * *$ & $0.019 * *$ & $-0.004 *$ & $-0.013 * * *$ & 0.0004 & $-0.016 * * *$ & $-0.022 * * *$ & $-0.008 * *$ & $-0.020 * * *$ \\
\hline & [0.038] & {$[0.040]$} & {$[0.070]$} & [0.002] & {$[0.700]$} & {$[0.000]$} & [0.003] & {$[0.022]$} & [0.001] \\
\hline \multirow[t]{2}{*}{ Cash } & $-0.037 * * *$ & $-0.039 * * *$ & $-0.040 * * *$ & $-0.131 * * *$ & $-0.145^{* * *}$ & $-0.099 * * *$ & $-0.083 * * *$ & 0.0001 & $-0.086 * * *$ \\
\hline & [0.000] & [0.000] & [0.000] & [0.000] & [0.000] & [0.000] & [0.000] & [0.957] & [0.000] \\
\hline Observations & 111,449 & 141,487 & $1,641,927$ & 43,393 & $1,193,518$ & 17,909 & 222,202 & $2,048,918$ & 101,422 \\
\hline No. of firms & 10,631 & 17,623 & 190,990 & 6,927 & 148,016 & 2,357 & 45,114 & 244,450 & 19,585 \\
\hline Firm fixed effects & Yes & Yes & Yes & Yes & Yes & Yes & Yes & Yes & Yes \\
\hline Year fixed effects & Yes & Yes & Yes & Yes & Yes & Yes & Yes & Yes & Yes \\
\hline
\end{tabular}

